\title{
ANALISIS IMPLEMENTASI DANA DESA DI WILAYAH MALUKU UTARA
}

\author{
Rusli Zulfian \\ Direktorat Pengelolaan Kas Negara \\ ruslizulfian@gmail.com
}

\begin{abstract}
ABSTRAK
This study aims to analyze four aspects of the implementation of the Village Fund program covering allocation, distribution, execution and reporting of the village fund and to provide recommendations on the issue of those four aspects. The research was conducted in three districts in North Maluku province between year 2015 and Semester I 2016, which are Tidore, West Halmahera and North Halmahera Regency. This study took three samples for each district so that the entire samples are nine villages. The research methods are descriptive qualitative analysis and descriptive quantitative analysis. Data was collected by collecting written documentation, conducting interviews, field observations and focus group discussion (FGD). The results showed that the basic allocation and allocation formula led to less proportional distribution Village Fund if associated with status/condition of the village, as mentioned in the Developing Village Index (IDM). The Delays in disbursement phase I have an impact on the disbursement for the next phases. There is inappropriate of the Village Fund usage, which is caused by the bias interpretation of two different regulations. In relation to transparency and accountability, some observed villages have not published the village fund report on the available media.
\end{abstract}

Penelitian ini bertujuan untuk menganalisis empat aspek pelaksanaan program Dana Desa yang meliputi aspek pengalokasian, penyaluran, penggunaan dan pelaporan Dana Desa serta memberikan rekomendasi atas permasalahan dari keempat aspek tersebut. Penelitian dilaksanakan di tiga kabupaten/kota di Provinsi Maluku Utara yaitu Kota Tidore Kepulauan, Kabupaten Halmahera Barat dan Kabupaten Halmahera Utara dengan rentang waktu pelaksanaan Dana Desa Tahun 2015 sampai dengan Semester I 2016. Penelitian ini mengambil tiga sampel untuk setiap kabupaten sehingga keseluruhan sampel berjumlah 9 (sembilan) desa. Metode analisis data dalam penelitian ini menggunakan pendekatan analisis deskriptif kuantitatif dan analisis desktiptif kualitatf. Sumber data diperoleh dari dokumentasi tertulis, wawancara, observasi lapangan dan pada tahap akhir penelitian diselenggarakan focus group discussion (FGD). Hasil penelitian menunjukkan alokasi dasar dan alokasi formula menyebabkan kurang proporsionalnya distribusi Dana Desa apabila dikaitkan dengan status/kondisi desa sebagaimana dituangkan dalam Indeks Desa Membangun (IDM). Keterlambatan penyaluran Dana Desa pada tahap I berdampak pada keterlambatan penyaluran Dana Desa tahap berikutnya. Terdapat beberapa penggunaan Dana Desa yang kurang sesuai prioritas karena bias penerjemahan dua regulasi yang berbeda. Dalam hal transparansi dan akuntabilitas, beberapa desa observasi belum mempublikasikan pelaporannya di media yang tersedia seperti balai desa. 


\section{PENDAHULUAN}

\subsection{Latar Belakang}

Undang Undang Nomor 6 Tahun 2014 tentang Desa yang telah disahkan pada tanggal 15 Januari 2014 membawa perubahan secara signifikan terhadap desa. Desa akan mengalami reposisi dan pendekatan baru dalam pelaksanaan pembangunan.

Selama ini, desa seolah terlupakan dari prioritas pembangunan. Akibatnya, kesenjangan antara kawasan perkotaan dengan kawasan perdesaan semakin melebar.

Data BPS menunjukkan nilai indeks kedalaman kemiskinan (P1) dan indeks keparahan kemiskinan (P2) di daerah perdesaan Maluku Utara maupun secara Nasional lebih tinggi dibandingkan dengan daerah perkotaan. Pada Maret 2016, nilai Indeks Kedalaman Kemiskinan (P1) untuk perkotaan Maluku Utara hanya 0,367 dan secara nasional sebesar 1,19 sementara di daerah perdesaan Maluku Utara mencapai 0,861 dan secara nasional 2,74. Nilai indeks keparahan kemiskinan (P2) untuk perkotaan Maluku Utara hanya 0,064 dan secara nasional sebesar 0,27 sedangkan di daerah perdesaan Maluku Utara mencapai 0,218 dan secara nasional 0,79. Hal ini menunjukkan bahwa penduduk miskin di daerah perdesaan baik di wilayah Maluku Utara maupun secara nasional lebih sulit untuk diangkat dari garis kemiskinan dibandingkan penduduk miskin di daerah perkotaan.

Untuk mengatasi kesenjangan pembangunan tersebut, Pemerintah memperkenalkan konsep membangun dari pinggiran dengan memperkuat daerah dan desa yang menjadi salah satu agenda prioritas pembangunan (nawacita). Dalam konsep tersebut, terjadi perubahan paradigma pembangunan dari "Membangun Desa" menjadi "Desa Membangun". Dengan paradigma Desa Membangun, desa yang semula bersifat pasif dan menjadi objek pembangunan berubah menjadi pelaku/subjek dan berpartisipasi aktif dalam pembangunan. Desa diharapakan menjadi salah satu sentra pembangunan. Akselerasi pembangunan di desa diharapkan mampu memacu pertumbuhan dan perkembangan desa bersangkutan sehingga mendorong penduduk desa untuk keluar dari kemiskinan serta dapat memberikan multiplier effect ke wilayah di atasnya dan secara berjenjang memberikan pengaruh positif bagi perekonomian nasional.

Untuk mencapai tujuan tersebut, pada tahun 2015 pemerintah mengalokasikan Dana Desa dalam APBN-P sebesar 20,77 triliun atau berkisar antara Rp240 juta-Rp270 juta untuk setiap desa dan pada tahun 2016 meningkat 125\% menjadi
46,9 triliun. Pada tahap awal, pelaksanaan Dana Desa masih banyak ditemui permasalahan mulai dari penyaluran, penggunaan sampai pertanggungjawaban antara lain penyaluran Dana Desa yang terlambat seperti yang dimuat dalam harian Kompas edisi 27 Agustus 2015, "Penyaluran Dana Desa tahun 2015 sebesar Rp20,77 triliun untuk 74.093 desa masih tersumbat, puluhan ribu desa belum menerima sepeser pun. Selain menggembosi daya tumbuh ekonomi, gagasan membangun dari pinggiran juga belum sepenuhnya terwujud". Selain masalah penyaluran, penggunaan Dana Desa juga banyak ditemui masalah. Kementerian Desa menyimpulkan ada penggunaan Dana Desa tahun 2015 yang melenceng atau tidak sesuai dengan tujuan Dana Desa, yang intinya digunakan untuk pembangunan dan pemberdayaan. Dana Desa yang digunakan bukan untuk pembangunan prioritas, antara lain digunakan untuk pembangunan kantor desa, rumah ibadah dan lapangan sepakbola1.

Mengingat banyak permasalahan yang ditemui dalam pelaksanaan Dana Desa maka perlu dilakukan suatu Kajian Dana Desa. Kajian tersebut diharapkan dapat menggambarkan kondisi riil pelaksanaan Dana Desa, memotret permasalahan yang dihadapi serta merumuskan rekomendasi yang bermanfaat sebagai bahan perumusan kebijakan maupun untuk mengatasi permasalahan teknis yang dihadapi. Kajian Dana Desa ini juga sebagai bentuk inisiasi partisipasi publik untuk melakukan studi, pemantauan dan publikasi terhadap praktik baik dan buruk desa dalam penerapan prioritas penggunaan Dana Desa sebagaimana tertuang dalam Pasal 15 Peraturan Menteri Desa Nomor 21 Tahun 2015.

\subsection{Tujuan Penelitian}

Fokus Kajian Dana Desa menekankan pada empat aspek penting yaitu Analisis Pengalokasian Dana Desa, Analisis Penyaluran Dana Desa, Analisis Penggunaan Dana Desa dan Analisis Pelaporan Dana Desa. Analisis tersebut bertujuan sebagai berikut:

1. Analisis Pengalokasian Dana Desa:

Untuk mengetahui ketepatan penyusunan formula pembagian rincian Dana Desa setiap desa.

2. Analisis Penyaluran Dana Desa:

Untuk mengetahui persyaratan, prosedur, dan ketepatan waktu penyaluran Dana Desa dari Rekening Kas Umum Daerah (RKUD) ke Rekening Kas Desa.

3. Analisis Penggunaan Dana Desa:

1 http://www.sapa.or.id/b1/132-pmk/9839dana-desa-mlenceng-kdjfj diakses pada tanggal 13 Juli 2016 
a. Untuk mengetahui ketepatan penggunaan Dana Desa sesuai dengan peruntukannya.

b. Untuk mengetahui potensi tumpang tindih pembiayaan program Dana Desa dengan program APBD/APBN.

c. Untuk mengetahui tingkat optimalisasi penggunaan Dana Desa.

d. Untuk mengetahui efektifitas dan kemanfaatan penggunaan Dana Desa.

4. Analisis Pelaporan Dana Desa:

a. Untuk mengetahui ketepatan waktu pelaporan Dana Desa.

b. Untuk mengetahui sistem pembukuan yang digunakan dan kesesuaiannya dengan regulasi yang ada.

c. Untuk mengetahui tingkat kesulitan dalam pembuatan laporan realisasi Dana Desa.

d. Untuk mengetahui transparansi dan akuntabilitas pelaporan Dana Desa.

5. Rekomendasi

Pada akhirnya analisis tersebut bermuara untuk memberikan solusi dan upaya yang dapat memperbaiki pelaksanaan Dana Desa.

\section{KERANGKA TEORI DAN PENGEMBANGAN HIPOTESIS}

\subsection{Kebijakan Desentralisasi Fiskal}

Lahirnya Undang Undang Nomor 22 Tahun 1999 tentang Pemerintahan Daerah menandakan lahirnya era desentralisasi dalam sistem pemerintahan Indonesia. Desentralisasi adalah penyerahan urusan pemerintahan oleh Pemerintah Pusat kepada daerah otonom berdasarkan asas otonomi. ${ }^{2}$ Penerapan desentralisasi dilandasi pemikiran untuk memberikan pelayanan umum yang lebih baik dan menciptakan proses pengambilan keputusan publik yang lebih demokratis. Namun, memindahkan tanggung jawab atas penyediaan pelayanan ke Pemerintah di tingkat yang lebih rendah bisa menjadi tidak produktif, jika tidak diikuti oleh desentralisasi keuangan untuk menopang tanggung jawab ini, yang biasanya disebut sebagai prinsip money follow function. ${ }^{3}$

Mengacu pada prinsip money follow function, terjadi pelimpahan wewenang Pemerintah yang diikuti dengan pelimpahan pendanaan sebagai

2 Definisi berdasarkan Undang Undang Nomor 23 Tahun 2014 tentang Pemerintahan Daerah.

3 Marwanto Harjowiryono. Pengembangan Sistem Pembiayaan Antar Pemerintah di Indonesia. Desentralisasi Fiskal di Indonesia Satu Dekade setelah Ledakan Besar. (Jakarta: DJPK, 2012) konsekuensi untuk membiayai pelaksanaan kewenangan tersebut. Akibatnya, Falleti (2004) mendefinisikan desentralisasi sebagai sebuah proses dan reformasi kebijakan yang bertujuan untuk mentransfer tanggung jawab, sumber daya, atau kewenangan dari tingkatan pemerintahan yang lebih tinggi kepada tingkatan pemerintahan yang lebih rendah. ${ }^{4}$ Dengan demikian desentralisasi pemerintahan diikuti dengan desentralisasi fiskal melalui proses distribusi anggaran dari tingkat pemerintah yang lebih tinggi kepada pemerintah yang lebih rendah.

Desentralisasi fiskal bertujuan: pertama, meningkatkan efisiensi pengalokasian sumber daya nasional maupun kegiatan pemerintah daerah; kedua, memenuhi aspirasi daerah, memperbaiki struktur fiskal dan mobilisasi pendapatan regional maupun nasional; ketiga, meningkatkan akuntabilitas, transparansi dan partisipasi masyarakat dalam pengambilan keputusan; keempat, memperbaiki keseimbangan fiskal antar daerah dan memastikan adanya pelayanan yang berkualitas di setiap darah; kelima, menciptakan kesejahteraan sosial bagi masyarakat daerah (Fuad, dkk. dalam Abidin, 2015).

\subsection{Instumen Desentralisasi Fiskal}

Esensi dari desentralisasi fiskal adalah diskresi daerah dalam mengalokasikan anggarannya sesuai kebutuhan dan prioritas daerahnya yang dapat dijalankan dengan satu set pendanaan yang meliputi pendapatan asli atau sumber sendiri dan mekanisme transfer. Transfer sebagai salah satu instumen kunci dalam desentralisasi fiskal diperlukan jika terjadi ketidakseimbangan vertikal maupun horizontal dan untuk memastikan bahwa pemerintah daerah dapat melaksanakan fungsi yang dialihkan ke mereka.

Bergvall, et al (2006) mengklasifikasikan transfer secara garis besar menjadi dua bagian yaitu yang bersifat earmarked dan non-earmarked. Transfer yang bersifat earmarked adalah transfer yang diberikan dengan syarat (conditional) hanya dapat digunakan untuk tujuan tertentu. Transfer yang bersifat non-earmarked merupakan transfer yang diberikan tanpa syarat (unconditional) dan biasanya dibagikan berdasarkan suatu formula tertentu. Pemerintah Daerah (Sub-National Government) memiliki kewenangan dalam

4 Tulia G. A Falleti. Sequential Theory of Decentralization and Its Effects On The Intergovernmental Balance of Power: Latin American Cases in Comparative Perspective. ( 2004) 
memanfaatkan dana transfer sesuai dengan pertimbangannya sendiri.

Baik transfer yang bersifat earmarked dan non-earmarked dapat bersifat mandatori maupun bersifat diskresioner. Transfer yang bersifat nonearmarked biasanya berupa transfer tanpa kewajiban, tetapi terkadang disertai ikatan tidak langsung yang melekat. Akibatnya, transfer yang bersifat non-earmarked dapat bersifat mandatori. Transfer yang bersifat mandatori menimbulkan konsekuensi kewajiban melakukan sesuatu berdasarkan peraturan dari pemerintah yang memberikan transfer tersebut. Sebagian besar transfer yang diberikan kepada Pemerintah Daerah (sub-national government) secara regular merupakan transfer yang bersifat mandatori.
Transfer yang bersifat earmarked dan mandatori terbagi menjadi matching grants dan non-matching grants. Transfer yang bersifat earmarked dan mandatori yang tidak dilengkapi dengan dana kontribusi pemerintah daerah merupakan transfer yang bersifat non-matching. Kemudian, transfer yang bersifat non-earmarked dan mandatori terbagi menjadi transfer yang bersifat general purpose grant dan block grant. Perbedaan dari kedua jenis transfer tersebut adalah block grant diberikan oleh pemberi transfer dengan tujuan tertentu. Alasan pemberian transfer bersifat block grant adalah untuk meningkatkan efisiensi penggunaan sumber daya di tingkat sub-national. Pengklasifikasian transfer secara lengkap dapat dilihat pada gambar berikut ini.

Gambar 1. Klasifikasi Transfer

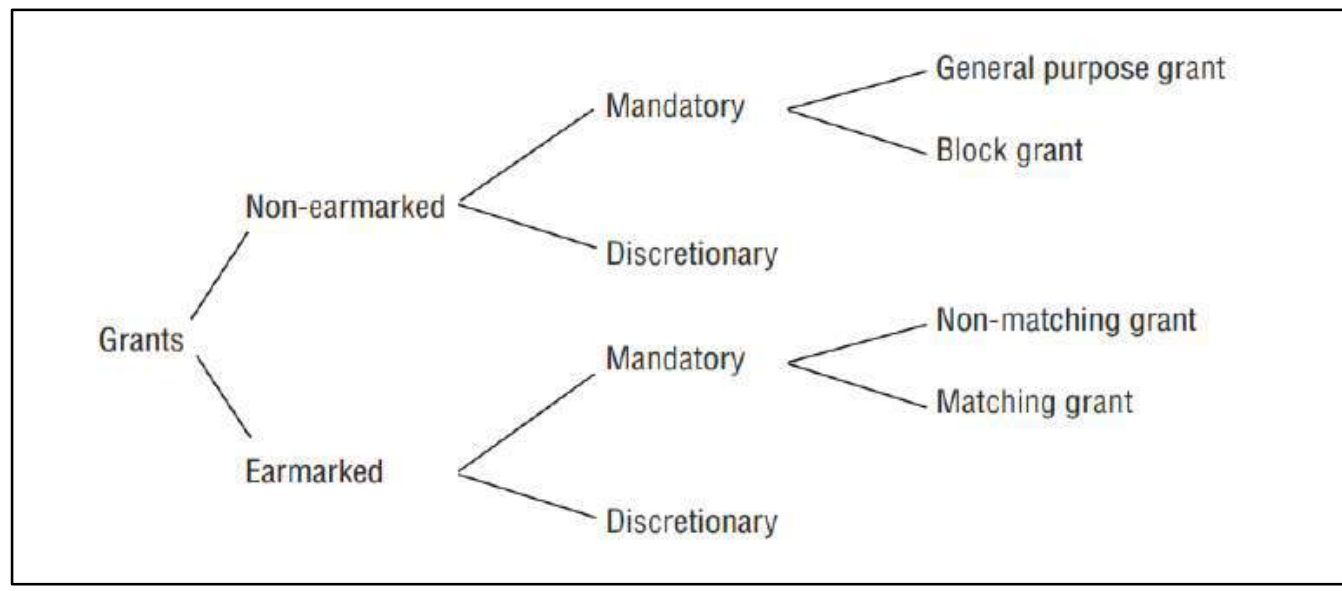

Sumber: Bergval, et al. Intergovernmental Transfers and Decentralised Public Spending (2006).

Perwujudan dari ciri Indonesia sebagai negara yang menganut desentralisasi fiskal adalah tersedianya alokasi anggaran transfer ke daerah dalam rangka mendanai pelaksanaan urusan yang telah diserahkan ke daerah dan bertujuan untuk mempercepat penguatan peran daerah dalam penyediaan pelayanan publik dan peningkatan kesejahteraan masyarakat. Adapun komponen anggaran transfer terbagi menjadi transfer ke daerah yang meliputi Dana Perimbangan, Dana Insentif Daerah, Dana Otonomi Khusus, dan Dana Keistimewaan DIY, selain itu juga dialokasikan dana yang bersumber dari APBN untuk mendanai pelaksanaan urusan yang telah diserahkan kepada desa atau disebut dengan Dana Desa.

\subsection{Dana Desa}

Konsep desentralisasi fiskal memungkinkan pemberian kekuasaan, kewenangan dan diskresi kepada pemerintah desa untuk mengatur dan menentukan penggunaan dana untuk melaksanakan urusan-urusannya (Mardiasmo, 2004). Otonomi desa memungkinkan pemerintah desa memiliki keleluasaan dalam pemanfaatan Dana Desa.

Berdasarkan Undang-Undang Nomor 6 Tahun 2014 tentang Desa, desa diberikan kewenangan untuk mengatur dan mengurus kewenangannya sesuai dengan kebutuhan dan prioritas desa. Dana Desa akan digunakan untuk mendanai keseluruhan kewenangan desa sesuai dengan kebutuhan dan prioritas Dana Desa tersebut. Namun, mengingat Dana Desa bersumber dari belanja pusat, optimalisasi penggunaan Dana Desa dilakukan dengan diberikan kewenangan pada Pemerintah untuk menetapkan prioritas penggunaan dana tersebut tetap sejalan dengan kewenangan yang menjadi tanggung jawab desa. ${ }^{5}$

Dana Desa yang ditransfer melalui APBD kabupaten/kota digunakan untuk tujuan tertentu yaitu untuk membiayai penyelenggaraan

5 Penjelasan Peraturan Pemerintah Nomor 60 Tahun 2014 tentang Dana Desa yang Bersumber dari Anggaran Pendapatan dan Belanja Negara 
pemerintahan, pelaksanaan pembangunan, pembinaan kemasyarakatan, dan pemberdayaan masyarakat. Dengan demikian, bila dikaitkan dengan klasifikasi transfer Dana Desa termasuk ke dalam jenis transfer yang bersifat non-earmarked mandatori dan bersifat block grant. Sebagai dana transfer, pengelolaan Dana Desa memiliki siklus yang serupa dengan pengelolaan dana transfer lainnya yaitu: penganggaran, pengalokasian, penyaluran, penggunaan dan pelaporan.

\subsubsection{Penganggaran Dana Desa}

Pemerintah menganggarkan Dana Desa secara nasional dalam APBN setiap tahun dan merupakan bagian dari anggaran belanja pusat nonkementerian/lembaga. Dalam Peraturan Pemerintah Nomor 22 tahun 2015 Pasal 30A menyebutkan bahwa pengalokasian anggaran Dana Desa dalam APBN dilakukan secara bertahap, yaitu pada Tahun Anggaran 2015 paling sedikit 3\%, Tahun Anggaran 2016 paling sedikit 6\%, dan Tahun Anggaran 2017 dan seterusnya sebesar $10 \%$ dari anggaran transfer daerah.

Namun, alokasi anggaran Dana Desa tersebut juga harus menyesuaikan dengan kemampuan keuangan negara. Apabila APBN belum dapat memenuhi alokasi sesuai persentase tersebut, alokasi anggaran Dana Desa ditentukan berdasarkan alokasi anggaran Dana Desa tahun sebelumnya.

Dalam masa transisi, sebelum Dana Desa mencapai 10\%, anggaran Dana Desa dipenuhi melalui realokasi dari Belanja Pusat dari program yang berbasis Desa. Kementerian/Lembaga mengajukan anggaran untuk program yang berbasis desa kepada menteri untuk ditetapkan sebagai sumber Dana Desa. Selanjutnya dalam hal Dana Desa telah dipenuhi sebesar $10 \%$ dari total dana transfer ke daerah maka penganggarannya sepenuhnya mengikuti mekanisme penganggaran dana Bendahara Umum Negara.

\subsubsection{Pengalokasian Dana Desa}

Pengalokasian Dana Desa meliputi 2 tahap yaitu:

1. Tahap pengalokasian dari APBN ke APBD

Berdasarkan pagu yang ditetapkan dalam APBN, pengalokasian dilaksanakan oleh Menteri Keuangan melalui Direktorat Jenderal Perimbangan Keuangan (DJPK). Rincian Dana Desa setiap kabupaten/kota dialokasikan secara merata dan berkeadilan berdasarkan alokasi dasar dan alokasi formula. sebagaimana yang diatur dalam Peraturan Pemerintah Nomor 22 tahun 2015 dan Peraturan Menteri Keuangan RI Nomor 49/PMK.07/2016. Besaran alokasi dasar setiap kabupaten/kota dihitung dengan cara mengalikan alokasi dasar dengan jumlah desa di kabupaten/kota. Sementara itu, alokasi formula yang besarannya $10 \%$ dari anggaran Dana Desa dihitung dengan bobot $25 \%$ untuk jumlah penduduk, $35 \%$ untuk angka kemiskinan, $10 \%$ untuk luas wilayah, dan 30\% tingkat kesulitan geografis. Penghitungan alokasi formula setiap kabupaten/kota sebagai berikut:

$\mathrm{AF} \mathrm{Kab} /$ kota $=((0,25+\mathrm{Y} 1)+(0,35+\mathrm{Y} 2)+(0,10+\mathrm{Y} 3)+$ $(0,30+Y 4)) *(0,10 * \mathrm{DD})$

Keterangan:

AF Kab/Kota : Alokasi Formula Kab/Kota

Y1 : rasio jumlah penduduk desa setiap kabupaten/kota terhadap total penduduk desa nasional

Y2 : rasio jumlah penduduk miskin desa setiap kabupaten/kota terhadap total penduduk miskin desa nasional

Y3 : rasio luas wilayah desa setiap kabupaten/kota terhadap luas wilayah desa nasional

Y4 : rasio Indeks Kemahalan Konstruksi (IKK) kabupaten/kota terhadap total IKK Kabupaten/kota yang dimiliki desa

DD: Pagu Dana Desa Nasional

2. Tahap pengalokasian dari APBD ke APB Desa Pengalokasian Dana Desa setiap desa dilaksakanan oleh bupati/walikota berdasarkan rincian Dana Desa setiap kabupaten/kota dan dialokasikan secara merata dan berkeadilan berdasarkan alokasi dasar dan alokasi formula seperti halnya dalam pengalokasian dari APBN ke APBD. Besaran alokasi dasar setiap desa dihitung dengan cara membagi alokasi dasar setiap kabupaten/kota dengan jumlah Desa di kabupaten/kota. Alokasi formula dihitung dengan bobot $25 \%$ untuk jumlah penduduk, $35 \%$ untuk angka kemiskinan, $10 \%$ untuk luas wilayah, dan 30\% tingkat kesulitan geografis.

Penghitungan alokasi formula setiap kabupaten/kota sebagai berikut:

$$
\begin{aligned}
\mathrm{AF} \text { setiap Desa }= & ((0,25+\mathrm{Z} 1)+(0,35+\mathrm{Z2})+(0,10+\mathrm{Z3})+ \\
& (0,30+\mathrm{Z} 4)) *(\mathrm{DD} \text { kab } / \text { kota }-\mathrm{AD} \\
& \mathrm{kab} / \text { kota })
\end{aligned}
$$

Keterangan:

AF setiap Desa : Alokasi Formula Setiap Desa

Z1 : rasio jumlah penduduk setiap desa terhadap total penduduk desa kabupaten/ Kota bersangkutan

Z2 : rasio jumlah penduduk miskin setiap desa terhadap total penduduk miskin desa kabupaten/kota bersangkutan

Z3 : rasio luas wilayah setiap desa terhadap luas wilayah desa kabupaten/kota yang bersangkutan 


\section{Halaman 60}

Z4 : rasio IKG setiap desa terhadap total IKG desa kabupaten/kota yang bersangkutan

\begin{tabular}{|c|c|c|}
\hline DD kab/kota & : besaran & Desa \\
\hline & kabupaten/kota & \\
\hline AD kab/kota & $\begin{array}{l}\text { : besaran Alokasi } \\
\text { kabupaten/kota }\end{array}$ & Dasar \\
\hline
\end{tabular}

Tata cara pembagian dan penetapan besaran Dana Desa ditetapkan dengan peraturan bupati/walikota yang paling sedikit mengatur mengenai: (a) tata cara penghitungan pembagian Dana Desa; (b) penetapan rincian Dana Desa; (c) mekanisme dan tahap penyaluran Dana Desa; (d) prioritas penggunaan Dana Desa; (e) penyusunan dan penyampaian laporan realisasi penggunaan Dana Desa; dan (f) sanksi.

\subsubsection{Penyaluran Dana Desa}

Dalam proses penyaluran Dana Desa terbagi dalam 2 tahap yaitu mekanisme transfer APBN dari rekening Kas Umum Negara (RKUN) ke Rekening Kas Umum Daerah (RKUD) dan tahap mekanisme transfer APBD dari RKUD ke kas desa. Penyaluran Dana Desa dari RKUN ke RKUD untuk tahun 2015 dilakukan dalam 3 tahap yaitu tahap I sebesar $40 \%$ di bulan April, tahap 2 sebesar $40 \%$ pada bulan Agustus, dan tahap 3 sebesar 20\% pada bulan Oktober dengan batas waktu penyaluran dana adalah paling lambat 14 hari kerja. Pada tahun 2016, pencairan dilaksanakan dalam 2 tahap yaitu tahap 1 sebesar $60 \%$ pada bulan Maret dan tahap 2 sebesar $40 \%$ pada bulan Agustus dengan batas waktu penyaluran lebih cepat yaitu paling lambat 7 hari kerja setelah Dana Desa diterima di RKUD.

\section{Tabel 1.Periode dan Persyaratan Penyaluran} Dana Desa Tahun 2015

\begin{tabular}{|c|c|c|c|}
\hline \multirow{2}{*}{$\begin{array}{l}\text { Uraian } \\
\text { Tahapan }\end{array}$} & \multicolumn{3}{|c|}{ Syarat Pencairan } \\
\hline & Tahap I & Tahap II & Tahap III \\
\hline Bulan & April & Agustus & Oktober \\
\hline Proporsi & $40 \%$ & $40 \%$ & $20 \%$ \\
\hline $\begin{array}{l}\text { Penyaluran } \\
\text { RKUN ke } \\
\text { RKUD }\end{array}$ & $\begin{array}{l}\text { - Perda APBD } \\
\text { - Perda tata cara } \\
\text { pembagian dan } \\
\text { penetapan rincian } \\
\text { Dana Desa (DD) } \\
\text { setiap Desa } \\
\text { - laporan realisasi } \\
\text { penyaluran dan } \\
\text { konsolidasi } \\
\text { penggunaan DD TA } \\
\text { sebelumnya } \\
\end{array}$ & $\begin{array}{l}\text { - Laporan } \\
\text { penyaluran } \\
\text { dan } \\
\text { konsolidasi } \\
\text { penggunaan } \\
\text { Tahap I } \\
\text { - Paling kurang } \\
\text { 50\% DD } \\
\text { Tahap I telah } \\
\text { disalurkan. }\end{array}$ & $\begin{array}{ll}\text { - } & \text { Laporan } \\
\text { penyaluran dan } \\
\text { konsolidasi } \\
\text { penggunaan } \\
\text { Tahap I dan } \\
\text { Tahap II } \\
\text { - } & \text { Paling kurang } \\
& \text { 50\% DD Tahap } \\
\text { I dan Tahap II } \\
\text { telah } \\
\text { disalurkan } \\
\end{array}$ \\
\hline $\begin{array}{l}\text { Penyaluran } \\
\text { RKUD ke } \\
\text { Kas Desa } \\
\text { (14 Hari } \\
\text { Kerja) }\end{array}$ & $\begin{array}{l}\text { - Perdes APB Desa } \\
\text { - laporan realisasi } \\
\text { penggunaan DD TA } \\
\text { sebelumnya }\end{array}$ & $\begin{array}{l}\text { - Laporan } \\
\text { penggunaan } \\
\text { DD Tahap I } \\
\text { - Penggunaan } \\
\text { DD Tahap 1 } \\
\text { sedikitnya } \\
50 \%\end{array}$ & $\begin{array}{ll}\text { - } & \text { Laporan } \\
& \text { penggunaan DD } \\
& \text { Tahap I dan II } \\
\text { - } & \text { Penggunaan DD } \\
& \text { sebesar 50\% }\end{array}$ \\
\hline
\end{tabular}

Tabel 2.Periode dan Persyaratan Penyaluran Dana Desa Tahun 2016

\begin{tabular}{|lll|}
\hline \multicolumn{1}{|c|}{ Uraian } & \multicolumn{2}{c|}{ Syarat Pencairan } \\
\hline Tahapan & Tahap I & Tahap II \\
\hline Bulan & Maret & Agustus \\
\hline
\end{tabular}

\begin{tabular}{|c|c|c|}
\hline Proporsi & $60 \%$ & $40 \%$ \\
\hline $\begin{array}{l}\text { Penyaluran } \\
\text { RKUN ke } \\
\text { RKUD }\end{array}$ & $\begin{array}{l}\text { - Perda mengenai APBD } \\
\text { TA berjalan } \\
\text { - Perda mengenai tata } \\
\text { cara pembagian dan } \\
\text { penetapan rincian DD } \\
\text { setiap Desa } \\
\text { - laporan realisasi } \\
\text { penyaluran dan } \\
\text { konsolidasi } \\
\text { penggunaan DD TA } \\
\text { sebelumnya }\end{array}$ & $\begin{array}{l}\text { Laporan penyaluran dan } \\
\text { konsolidasi penggunaan } \\
\text { Tahap I } \\
\text { - Paling kurang 50\% DD } \\
\text { Tahap I telah disalurkan } \\
\text { dan digunakan. }\end{array}$ \\
\hline $\begin{array}{l}\text { Penyaluran } \\
\text { RKUD ke Kas } \\
\text { Desa } \\
\text { (7 hari kerja) }\end{array}$ & 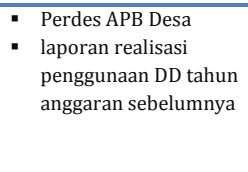 & $\begin{array}{l}\text { - Laporan penggunaan DD } \\
\text { Tahap I telah } \\
\text { disampaikan oleh kades } \\
\text { ke bupati/walikota } \\
\text { - Paling kurang 50\% DD } \\
\text { Tahap I telah digunakan }\end{array}$ \\
\hline
\end{tabular}

\subsubsection{Penggunaan Dana Desa}

Filosofi dari Dana Desa adalah meningkatkan kesejahteraan dan pemerataan pembangunan desa melalui peningkatan pelayanan publik di desa, memajukan perekonomian desa, mengatasi kesenjangan pembangunan antar desa serta memperkuat masyarakat desa sebagai subjek dari pembangunan. Sebagaimana tercantum dalam Peraturan Pemerintah Nomor 60 Tahun 2014 Pasal 19 bahwa penggunaan Dana Desa diprioritaskan untuk membiayai pembangunan dan pemberdayaan masyarakat, selanjutnya secara lebih khusus prioritas penggunaannya diatur dalam Peraturan Menteri Desa (Permendes) Nomor 21 Tahun 2015 tentang Penetapan prioritas penggunaan Dana Desa tahun 2016. Prioritas Dana Desa disusun tidak membatasi prakarsa lokal dalam merancang program/kegiatan pembangunan prioritas yang dituangkan ke dalam dokumen RKP Desa dan APBDesa. Prioritas tersebut memberikan pandangan prioritas penggunaan Dana Desa sehingga desa tetap memiliki ruang untuk berkreasi membuat program/kegiatan desa sesuai dengan kewenangannya, analisis kebutuhan prioritas dan sumber daya yang dimilikinya. ${ }^{6}$

Adanya pengaturan penggunaan digunakan oleh Desa sebagai acuan untuk menentukan program dan kegiatan yang dibiayai oleh Dana Desa dan merupakan kewenangan hak asal usul dan kewenangan lokal berskala desa. Penggunaan Dana Desa mendasarkan pada 3 prinsip yaitu:

a. Keadilan

Mengutamakan hak atau kepentingan seluruh warga desa tanpa membeda-bedakan

b. Kebutuhan prioritas

Mendahulukan yang kepentingan desa yang lebih mendesak, lebih dibutuhkan dan berhubungan langsung dengan kepentingan sebagian besar masyarakat desa

c. Tipologi desa

${ }^{6}$ Pokok-Pokok Kebijakan Prioritas Penggunaan Dana Desa Tahun 2016. Ditjen Pembangunan dan Pemberdayaan Masyarakat Desa 
Mempertimbangkan keadaan dan kenyataan karakteristik geografis, sosiologis, antropologis, ekonomi, dan ekologi desa yang khas, serta perubahan atau perkembangan kemajuan desa.

Penggunaan Dana Desa diprioritaskan untuk membiayai pelaksanaan program dan kegiatan berskala lokal desa bidang Pembangunan Desa dan Pemberdayaan Masyarakat Desa. Kegiatan Pembangunan Desa, meliputi:

a. pembangunan, pengembangan, dan pemeliharaan infrasruktur atau sarana dan prasarana fisik untuk penghidupan, termasuk ketahanan pangan dan permukiman;

b. pembangunan, pengembangan dan pemeliharaan sarana dan prasarana kesehatan masyarakat;

c. pembangunan, pengembangan dan pemeliharaan sarana dan prasarana pendidikan, sosial dan kebudayaan;

d. pengembangan usaha ekonomi masyarakat, meliputi pembangunan dan pemeliharaan sarana prasarana produksi dan distribusi; atau

e. pembangunan dan pengembangan saranaprasarana energi terbarukan serta kegiatan pelestarian lingkungan hidup.

Dalam rangka menyusun prioritas penggunaan Dana Desa, indikator yang digunakan oleh Pemerintah Desa adalah menggunakan data Indeks Desa Membangun (IDM) yang ditetapkan oleh Kementerian Desa, Pembangunan Daerah Tertinggal, dan Transmigrasi. IDM disusun berdasarkan indeks komposit yang dibangun dari dimensi sosial, ekonomi, dan budaya. Ketiga dimensi tersebut selanjutnya di-break down ke dalam variabel sampai dengan indikator operasional, seperti indikator waktu tempuh ke prasarana kesehatan, ketersediaan tenaga kesehatan, akses ke pendidikan dasar, kebiasaan gotong royong, sumber air bersih, akses internet, dan bermacam indikator lainnya. Terdapat 5 (lima) klasifikasi desa dalam IDM, yaitu:

1. Desa sangat Tertinggal (IDM $\leq 0,491)$

2. Desa Tertinggal (IDM $>0,491$ dan $\leq 0,599$ )

3. Desa Berkembang (IDM $>0,599$ dan $\leq 0,707$ )

4. Desa Maju (IDM $>0,707$ dan $\leq 0,815)$

5. Desa Mandiri (IDM $>0,815$ )

Klasifikasi dalam 5 status desa tersebut dapat menjadi rekomendasi kebijakan yang diperlukan khususnya dalam prioritas penggunaan Dana Desa, kegiatan Pemberdayaan Masyarakat berdasarkan tipologi desa yaitu:

a. Desa tertinggal dan/atau sangat tertinggal, mengutamakan kegiatan pemberdayaan masyarakat yang berorientasi pada membuka lapangan kerja dan atau usaha baru, serta bantuan penyiapan infrastruktur bagi terselenggaranya kerja dan usaha warga atau masyarakat baik dari proses produksi sampai pemasaran produk, serta pemenuhan kebutuhan atau akses kehidupan masyarakat desa;

b. Desa berkembang, memprioritaskan pemberdayaan masyarakat yang bertujuan untuk meningkatkan kuantitas dan kualitas kerja dan atau proses produksi sampai pemasaran produk, serta pemenuhan kebutuhan atau akses modal/fasilitas keuangan;

c. Desa maju dan atau mandiri, mengembangkan kegiatan pemberdayaan masyarakat yang visioner dengan menjadikan desa sebagai lumbung ekonomi atau kapital rakyat, dimana desa dapat menghidupi dirinya sendiri atau memiliki kedaulatan ekonomi, serta mampu mengembangkan potensi atau sumberdaya ekonomi atau manusia dan kapital desa secara berkelanjutan

\subsubsection{Pelaporan Dana Desa}

Pelaporan mengenai Dana Desa diatur dalam Peraturan Menteri Keuangan Nomor 49 tahun 2016, bahwa Kepala Desa menyampaikan laporan realisasi penggunaan Dana Desa setiap tahap kepada bupati/walikota. Laporan realisasi penggunaan Dana Desa yang disusun terdiri atas laporan realisasi penggunaan Dana Desa tahun anggaran sebelumnya dan laporan realisasi penggunaan Dana Desa tahap I. Laporan tersebut disampaikan paling lambat minggu kedua bulan Februari tahun anggaran berjalan. Setelah laporan dari setiap desa terkumpul, selanjutnya bupati/walikota menyampaikan laporan realisasi penyaluran dan konsolidasi penggunaan Dana Desa kepada Menteri Keuangan dengan tembusan Menteri Dalam Negeri, Menteri Desa, Pembangunan Daerah Tertinggal dan Transmigrasi.

Selain laporan Dana Desa, Kepala Desa sebagai penanggung jawab dari pengelolaan keuangan desa secara keseluruhan, dalam Peraturan Pemerintah Nomor 43 tahun 2014 dan Peraturan Menteri Dalam Negeri Nomor 113 Tahun 2014 diwajibkan menyampaikan laporan realisasi pelaksanaan APBDesa kepada Bupati/Walikota setiap semester tahun berjalan (laporan semesteran) dan laporan pertanggungjawaban realisasi pelaksanaan APBDesa setiap akhir tahun anggaran (laporan tahunan). Laporan yang dibuat oleh Kepala Desa ditujukan kepada Bupati/Walikota tersebut disampaikan melalui camat. Dalam laporan yang disusun tersebut terlihat bahwa laporan pertanggungjawaban yang harus dibuat oleh 
Kepala Desa harus terintegrasi secara utuh, tidak melihat sumber dana yang diperoleh desa.

\subsection{Penelitian Terdahulu}

Penelitian tentang keuangan desa dan pelaksanaan Dana Desa dengan berbagai aspek sudah pernah dilakukan sebelumnya. Sebagai contoh, penelitian yang dilakukan oleh Komisi Pemberantasan Korupsi (2015) mengenai sistem pengelolaan keuangan desa. Penelitian yang dilakukan oleh KPK dilakukan terhadap pengelolaan keuangan desa yang berasal dari Dana Desa dan Alokasi Dana Desa secara umum dengan tujuan untuk mendeteksi potensi korupsi dalam pengelolaan keuangan desa. Penelitian dilakukan dengan mengambil sampel pada lima kabupaten yaitu: Kabupaten Bogor, Kabupaten Klaten, Kabupaten Kampar, Kabupaten Gowa, dan Kabupaten Magelang. Data diperoleh melalui observasi lapangan, studi dokumentasi, dan melakukan focus group discusion. Hasil kajian KPK menemukan adanya potensi masalah dalam pengelolaan keuangan desa, yaitu: potensi masalah dalam regulasi dan kelembagaan; potensi masalah dalam tata laksana; potensi masalah dalam pengawasan; dan potensi masalah dalam sumber daya manusia.

Penelitian tentang keuangan desa juga dilakukan oleh Muhammad Zainul Abidin (2015). Penelitian bertujuan untuk mengetahui pelaksanaan keuangan desa dan penggunaan Alokasi Dana Desa (ADD) dalam mendukung kebijakan Dana Desa berdasarkan UU Nomor 6 Tahun 2014 tentang Desa. Metode analisis data menggunakan pendekatan kualitatif deskriptif, data diperoleh melalui studi pustaka. Hasil penelitian menunjukkan pelaksanaan keuangan desa telah didasarkan pada Peraturan Menteri Dalam Negeri Nomor 37 tahun 2007 tentang Pedoman Pengelolaan Keuangan Desa. Kendala yang dihadapi dalam pengelolaan keuangan desa disebabkan antara lain, kurangnya keberadaan dan kapasitas perangkat desa serta kemandirian keuangan. Dari sisi penggunaan ADD telah dilaksanakan berdasarkan Peraturan Pemerintah Nomor 72 Tahun 2005 tentang Desa dan disalurkan untuk pembangunan pedesaan, pengembangan masyarakat dan meningkatkan pendapatan.

Ilyasa Ardhi (2016) melakukan penelitian terhadap pelaksanaan Dana Desa pada Kabupaten Pacitan, Jawa Timur dengan mengambil tujuh desa sebagai sampel dari tiga kecamatan yang berbeda. Penelitian itu bertujuan menganalisis pelaksanaan program Dana Desa dan mencari penyebab terjadinya keterlambatan penyerapan Dana Desa pada tahun 2015. Metode analisis data dalam penelitian tersebut adalah kualitatif deskriptif.
Data diperoleh dari wawancara dan studi pustaka. Hasil penelitian menunjukkan bahwa keterlambatan penyerapan Dana Desa disebabkan ketidaksempurnaan peraturan yang mendasari pelaksanaan program Dana Desa. Di samping itu, BPMPD Kabupaten Pacitan menghadapi kendala dalam penginterpretasian peraturan terkait pelaksanaan program Dana Desa.

Berbeda dengan penelitian yang dilakukan oleh KPK dan Muhammad Zainul Abidin yang membahas pengelolaan keuangan desa yang berasal dari Dana Desa dan Alokasi Dana Desa secara umum, penelitian ini fokus membahas Dana Desa secara komprehensif. Penelitian ini membahas Dana Desa mulai dari pengalokasian, penyaluran, penggunaan sampai dengan pelaporan sehingga lebih luas dibandingkan penelitian yang dilakukan oleh Ilyasa Ardhi yang difokuskan pada keterlambatan dalam penyerapan Dana Desa.

\section{METODOLOGI PENELITIAN}

\subsection{Objek Penelitian}

Objek penelitian ini adalah Dana Desa yang bersumber dari APBN yang menjadi bagian dari Dana Transfer Pemerintah Pusat kepada Pemerintah Daerah dan disalurkan kembali ke setiap Desa. Mengingat keterbatasan waktu penelitian maka kajian ini hanya membatasi untuk pelaksanaan Dana Desa yang dilaksanakan di tiga kabupaten/kota Provinsi Maluku Utara yaitu Kota Tidore Kepulauan, Kabupaten Halmahera Barat dan Kabupaten Halmahera Utara dengan rentang waktu pelaksanaan Dana Desa Tahun 2015 sampai dengan Semester I 2016.

\subsection{Jenis Data dan Metode Pengumpulan Data}

Penelitian ini menggunakan data sekunder dan data primer. Data sekunder dikumpulkan dengan melakukan desk-study berupa study literature peraturan terkait Dana Desa, dan menggunakan basis data ataupun informasi kuantitatif dan kualitatif yang telah tersedia, seperti data alokasi anggaran Dana Desa, data realisasi Dana Desa, data statistik potensi desa, dan lainnya. Data primer dikumpulkan melalui kegiatan wawancara langsung (in-depth interview) dengan Pejabat Badan Pemberdayaan Masyarakat Desa Kabupaten/Kota, Badan/Dinas Pengelolaan Keuangan dan Aset Daerah, Perangkat Desa serta masyarakat desa pada saat observasi lapangan. Observasi lapangan juga dilakukan untuk melihat kondisi fisik proyek yang dibiayai dengan menggunakan Dana Desa serta melihat sistem pembukuan keuangan desa. Pada tahap akhir penyusunan kajian diselenggarakan focus group discussion (FGD) yang melibatkan Ekonom Kementerian Keuangan dan BPMPD 
Kabupaten/Kota dalam rangka memperkaya analisis, membantu merumuskan rekomendasi dan memperoleh masukan atas hasil kajian.

\subsection{Populasi dan Sampel}

Penentuan desa yang dipilih sebagai sampel observasi lapangan menggunakan metode purposive sampling mempertimbangkan aksesibilitas lokasi desa dan klasifikasi desa. Klasifikasi desa menggunakan Indeks Desa Membangun (IDM) yang dikembangkan oleh Kementerian Desa dan Pembangunan Daerah Tertinggal dan Transmigrasi. Desa yang dipilih sebagai sampel observasi lapangan ditetapkan 3 desa untuk setiap kabupaten sehingga keseluruhan sampel observasi lapangan sebanyak 9 desa. Keseluruhan sampel observasi telah dapat mewakili seluruh klasifikasi Desa sesuai dengan IDM. Rincian desa yang menjadi sampel observasi lapangan dapat dilihat pada tabel 3 berikut ini.

Tabel 3.Penentuan Desa Sampel Observasi

\begin{tabular}{|l|r|c|c|c|l|}
\hline \multirow{2}{*}{$\begin{array}{l}\text { Klasifikasi } \\
\text { Desa }\end{array}$} & \multicolumn{2}{|c|}{ IDM } & \multicolumn{3}{c|}{ Sampel Observasi } \\
\cline { 2 - 6 } & $\begin{array}{c}\text { Jmlh } \\
\text { Desa }\end{array}$ & $\%$ & $\begin{array}{c}\text { Jmlh } \\
\text { Desa }\end{array}$ & $\%$ & $\begin{array}{c}\text { Nama Desa } \\
\text { Observasi }\end{array}$ \\
\hline Mandiri & - & - & - & - & - \\
\hline Maju & 10 & 0,94 & 1 & 11,11 & $\begin{array}{l}\text { Guaemaadu } \\
\text { (Halmahera Barat) }\end{array}$ \\
\hline $\begin{array}{l}\text { Berkem- } \\
\text { bang }\end{array}$ & 150 & 14,07 & 1 & 11,11 & $\begin{array}{l}\text { Bobanehena } \\
\text { (Halmahera Barat) }\end{array}$ \\
\hline Tertinggal & 557 & 52,25 & 5 & 55,56 & $\begin{array}{l}\text { Wari Ino, Wari, } \\
\text { Pitu (Halmahera } \\
\text { Utara) } \\
\text { Maitara, Maitara } \\
\text { Tengah (Tidore } \\
\text { Kepulauan) }\end{array}$ \\
\hline
\end{tabular}

\begin{tabular}{|l|c|c|c|c|l|}
\hline $\begin{array}{l}\text { Sangat } \\
\text { Tertinggal }\end{array}$ & 349 & 32,74 & 2 & 22,22 & $\begin{array}{l}\text { Ulo (Halmahera } \\
\text { Barat) } \\
\text { Maitara Utara } \\
\text { (Tidore } \\
\text { Kepulauan) }\end{array}$ \\
\hline Jumlah & 1.066 & 100,00 & 9 & 100,00 & \\
\hline
\end{tabular}

Observasi lapangan dilakukan pada tanggal 20 s.d. 22 Juli 2016 untuk sampel observasi wilayah Tidore Kepulauan, tanggal 25 s.d. 28 Juli 2016 untuk sampel observasi wilayah Halmahera Utara dan tanggal 26 s.d. 28 Juli 2016 untuk sampel observasi wilayah Halmahera Barat.

\subsection{Metode Analisis Data}

Selanjutnya data yang telah diperoleh kemudian dianalisis dengan menggunakan pendekatan analisis deskriptif kuantitatif dan analisis desktiptif kualitatf. Analisis deskriptif kuantitatif memiliki tujuan untuk memberikan gambaran (deskripsi) mengenai suatu data baik data alokasi Dana Desa, realisasi Dana Desa, indikator-indikator desa, maupun data lainnya yang tersaji agar menjadi lebih mudah dipahami dan informatif. Analisis deskriptif kualitatif digunakan untuk menggambarkan keseluruhan fenomena yang terjadi berdasarkan data yang diperoleh. Berdasarkan analisis tersebut akan dirumuskan saran dan rekomendasi yang tepat. Secara lebih detail aktivitas yang dilakukan untuk memenuhi tujuan penelitian dapat dilihat pada tabel 4 berikut ini.

\section{Tabel 4. Aktivitas Penelitian Untuk Memenuhi Tujuan Penelitian}

\begin{tabular}{|c|c|c|}
\hline Aspek & Tujuan Penelitian & Aktivitas Penelitian \\
\hline $\begin{array}{c}\text { ANALISIS } \\
\text { PENGALOKASIAN }\end{array}$ & $\begin{array}{l}\text { Untuk mengetahui } \\
\text { ketepatan formula } \\
\text { pengalokasian }\end{array}$ & $\begin{array}{l}\text { - Reviu formula pengalokasian } \\
\text { - Reviu Peraturan Bupati dan kertas kerja penyusunan alokasi formula Dana } \\
\text { Desa } \\
\text { - Membandingkan secara sampel dasar perhitungan dengan data lain dari BPS } \\
\text { - Melakukan wawancara dengan Pihak BPMD/DPPKAD Kabupaten mengenai } \\
\text { proses perhitungan alokasi formula }\end{array}$ \\
\hline $\begin{array}{c}\text { ANALISIS } \\
\text { PENYALURAN }\end{array}$ & $\begin{array}{l}\text { Untuk mengetahui } \\
\text { persyaratan, prosedur, dan } \\
\text { ketepatan waktu } \\
\text { penyaluran }\end{array}$ & $\begin{array}{l}\text { - Melakukan analisis laporan konfirmasi transfer Dana Desa dan laporan } \\
\text { penyaluran Dana Desa dari RKUD ke RKDes } \\
\text { - Mereviu kapan Perda APBD dan Perhitungan alokasi Dana Desa ditetapkan } \\
\text { - Reviu Peraturan Bupati mengenai Petunjuk Teknis Pelaksanaan Dana Desa } \\
\text { aspek penyaluran } \\
\text { - Melakukan wawancara dengan BPMD/DPPKAD Kabupaten mengenai } \\
\text { penerimaan Dana Desa dari pemerintah pusat dan penyaluran ke rekening } \\
\text { desa }\end{array}$ \\
\hline \multirow[t]{2}{*}{$\begin{array}{c}\text { ANALISIS } \\
\text { PENGGUNAAN }\end{array}$} & $\begin{array}{l}\text { Untuk mengetahui } \\
\text { ketepatan penggunaan } \\
\text { Dana Desa sesuai dengan } \\
\text { peruntukannya }\end{array}$ & $\begin{array}{l}\text { - Reviu laporan realisasi Dana Desa untuk mengetahui porsi penggunaan Dana } \\
\text { Desa setiap kategori dan membandingkan dengan dokumen perencanaan. } \\
\text { - Reviu RPJMDes, RKPDes dan APBDes } \\
\text { - Reviu Peraturan Bupati mengenai petunjuk teknis pelaksanaan Dana Desa } \\
\text { - Melakukan wawancara dengan Pihak BPMD dan perangkat desa mengenai } \\
\text { proses perencanaan program sampai penyusunan APBDes } \\
\text { - Melakukan wawancara dengan perangkat desa dan masyarakat desa } \\
\text { mengenai keterlibatan/partisipasi masyarakat terhadap proyek/kegiatan } \\
\text { yang dibiayai dengan Dana Desa }\end{array}$ \\
\hline & $\begin{array}{l}\text { Untuk mengetahui potensi } \\
\text { tumpang tindih } \\
\text { pembiayaan program Dana } \\
\text { Desa dengan program } \\
\text { APBD/APBN }\end{array}$ & $\begin{array}{l}\text { - Melakukan wawancara dengan Pihak BPMD dan perangkat desa mengenai } \\
\text { proses perencanaan program yang dibiayai Dana Desa dan mekanisme yang } \\
\text { dilakukan untuk menghindari tumpang tindih pembiayaan dengan } \\
\text { APBN/APBD }\end{array}$ \\
\hline
\end{tabular}




\section{Halaman 64}

\begin{tabular}{|c|c|c|}
\hline Aspek & Tujuan Penelitian & Aktivitas Penelitian \\
\hline & $\begin{array}{l}\text { Untuk mengetahui tingkat } \\
\text { optimalisasi penggunaan } \\
\text { Dana Desa }\end{array}$ & $\begin{array}{l}\text { - Reviu laporan realisasi Dana Desa } \\
\text { - Melakukan wawancara dengan perangkat desa mengenai realisasi Dana } \\
\text { Desa, penggunaan harga standar dan mekanisme penyetoran pajak dan } \\
\text { peran dari tenaga pendamping. }\end{array}$ \\
\hline & $\begin{array}{l}\text { Untuk mengetahui tingkat } \\
\text { efektivitas dan } \\
\text { kemanfaatan penggunaan } \\
\text { Dana Desa }\end{array}$ & $\begin{array}{l}\text { - Melakukan observasi lapangan proyek yang dibiayai dengan Dana Desa } \\
\text { - Melakukan wawancara dengan masyarakat mengenai urgensi dan manfaat } \\
\text { proyek yang dibiayai dari Dana Desa }\end{array}$ \\
\hline \multirow{4}{*}{$\begin{array}{l}\text { ANALISIS } \\
\text { PELAPORAN }\end{array}$} & $\begin{array}{l}\text { Untuk mengetahui } \\
\text { ketepatan waktu pelaporan }\end{array}$ & $\begin{array}{l}\text { - Reviu laporan realisasi Dana Desa } \\
\text { - Reviu daftar pengawasan ketepatan waktu laporan Dana Desa }\end{array}$ \\
\hline & $\begin{array}{l}\text { Untuk mengetahui sistem } \\
\text { pembukuan yang } \\
\text { digunakan dan } \\
\text { kesesuaiannya dengan } \\
\text { regulasi yang ada }\end{array}$ & $\begin{array}{l}\text { - Reviu laporan realisasi Dana Desa } \\
\text { - Melakukan wawancara dengan perangkat desa mengenai sistem, dan SDM } \\
\text { yang terlibat dalam proses penyusunan laporan realisasi Dana Desa. }\end{array}$ \\
\hline & $\begin{array}{l}\text { Untuk mengetahui tingkat } \\
\text { kesulitan dalam } \\
\text { pembuatan laporan } \\
\text { realisasi Dana Desa }\end{array}$ & $\begin{array}{l}\text { - Melakukan wawancara dengan perangkat desa mengenai tingkat kesulitan } \\
\text { dalam proses penyusunan laporan realisasi Dana Desa }\end{array}$ \\
\hline & $\begin{array}{l}\text { Untuk mengetahui } \\
\text { transparansi dan } \\
\text { akuntabilitas pelaporan } \\
\text { Dana Desa }\end{array}$ & $\begin{array}{l}\text { - Melakukan observasi proses pembukuan dan penyimpanan bukti-bukti } \\
\text { pengeluaran Dana Desa } \\
\text { - Melakukan wawancara dengan masyarakat mengenai keterbukaan informasi } \\
\text { atas program Dana Desa, APBDes dan laporan realisasi Dana Desa } \\
\text { - Melakukan wawancara dengan pihak BPMD mengenai saluran pengaduan } \\
\text { atas penyimpangan Dana Desa } \\
\text { - Melakukan wawancara dengan masyarakat atas persepsi masyarakat apabila } \\
\text { ditemukan penyimpangan Dana Desa } \\
\text { - Melakukan wawancara dengan perangkat desa mengenai persepsi perangkat } \\
\text { desa atas peranan laporan realisasi Dana Desa }\end{array}$ \\
\hline REKOMENDASI & $\begin{array}{l}\text { Memberikan solusi dan } \\
\text { upaya yang dapat } \\
\text { memperbaiki pelaksanaan } \\
\text { Dana Desa }\end{array}$ & $\begin{array}{l}\text { - Melakukan indentifikasi pelaksanaan Dana Desa yang tidak sesuai dengan } \\
\text { peraturan } \\
\text { - Melakukan analisis akar masalah yang menjadi hambatan pelaksanaan Dana } \\
\text { Desa } \\
\text { - Merumuskan solusi dan saran yang dapat memperbaiki pelaksanaan Dana } \\
\text { Desa } \\
\text { - Melakukan Focus Group Discussion (FGD) dengan Ekonom Kementerian } \\
\text { Keuangan dan BPMPD Kabupaten/Kota untuk memperkaya analisis, reviu } \\
\text { hasil kajian dan membantu merumuskan rekomendasi. }\end{array}$ \\
\hline
\end{tabular}

\section{HASIL PENELITIAN}

\subsection{Analisis Pengalokasian Dana Desa}

a. Perbandingan Alokasi Dana Desa dengan Status Desa (IDM)

Pengalokasian Dana Desa TA 2015 dan TA 2016 dilakukan berdasarkan rasio alokasi dasar sebesar $90 \%$ dan alokasi formula sebesar $10 \%$. Besaran itu memperlihatkan semangat pengalokasian Dana Desa adalah pemerataan kepada tiap desa. Sementara itu, alokasi formula yang dihitung dengan memperhatikan kondisi desa ditetapkan $10 \%$ dengan bobot $25 \%$ untuk jumlah penduduk; $35 \%$ untuk angka kemiskinan; $10 \%$ untuk luas wilayah; dan $30 \%$ untuk tingkat kesulitan geografis. Memerhatikan pembagian bobot yang terdapat pada alokasi formula, maka angka kemiskinan dan tingkat kesulitan geografis pada suatu desa memiliki bobot yang besar. Indikasinya, kedua hal itu merupakan indikator yang lebih mempunyai pengaruh signifikan terhadap kemandirian suatu desa.
Tabel 5. Alokasi Dana Desa Tahun 2016

(dalam Jutaan Rupiah)

\begin{tabular}{|lccccc|} 
& & \multicolumn{3}{c}{ AF } & \multicolumn{3}{c}{ Alokasi per Desa } \\
\cline { 3 - 6 } Kab/Kota & AD & $\begin{array}{c}\text { Ter- } \\
\text { tinggi }\end{array}$ & $\begin{array}{c}\text { Ter- } \\
\text { rendah }\end{array}$ & $\begin{array}{c}\text { Ter- } \\
\text { tinggi }\end{array}$ & $\begin{array}{c}\text { Ter- } \\
\text { rendah }\end{array}$ \\
\hline Tidore & 565 & 203 & 34 & 768 & 599 \\
\hline $\begin{array}{l}\text { Halmahera } \\
\text { Barat }\end{array}$ & 565 & 100 & 11 & 665 & 576 \\
\hline $\begin{array}{l}\text { Halmahera } \\
\text { Utara }\end{array}$ & 565 & 93 & 14 & 658 & 579 \\
\hline
\end{tabular}

Sumber: BPMD Kab/Kota (data diolah)

Pengalokasian Dana Desa pada ketiga kabupaten/kota tersebut menunjukkan bahwa dengan penggunaan komposisi alokasi dasar dan alokasi formula 90\%:10\% maka besaran anggaran Dana Desa yang didapatkan oleh masing-masing desa belum sejalan dengan IDM yang terdapat pada masing-masing kabupaten/kota yang diobservasi. Perhitungan alokasi 90\%:10\% menyebabkan kurang proporsionalnya distribusi Dana Desa apabila dikaitkan dengan status/kondisi desa sebagaimana dituangkan dalam IDM.

Di Kota Tidore Kepulauan, desa dengan IDM terkecil adalah Desa Nuku (0,4462/Sangat Tertinggal). Dapat dikatakan bahwa semestinya 
desa ini layak mendapatkan Dana Desa dengan jumlah yang paling besar. Namun dengan perhitungan alokasi 90\%:10\% justru Desa Selamalofo $(0,4507 /$ Sangat Tertinggal $)$ yang mendapatkan Dana Desa yang paling besar. Demikian pula sebaliknya, untuk anggaran Dana Desa yang paling kecil, jika melihat pada IDM yang paling tinggi maka semestinya Desa Balbar $(0,6523$ /Berkembang) yang mendapatkan anggaran yang paling kecil, namun justru Desa Maitara Tengah (0,59/Tertinggal) yang mendapatkan anggaran paling kecil. Hal yang sama juga terjadi pada dua daerah observasi lainnya.

Dari contoh hasil perhitungan alokasi 90\%:10\% tersebut di atas, dapat disimpulkan bahwa dengan komposisi alokasi dasar yang sangat dominan dibandingkan alokasi berdasarkan formula belum sepenuhnya mencerminkan keadilan distributif (distributive justice) bagi setiap desa. Keadilan secara distributif bermakna bahwa anggaran Dana Desa berkorelasi dengan status/kondisi desa. Oleh sebab itu Pemerintah Pusat dalam hal ini perlu meninjau kembali komposisi yang lebih ideal antara alokasi dasar dengan alokasi berdasarkan formula. Salah satu pertimbangan yang dapat digunakan adalah dengan mengharmonisasi dan menyesuaikan IDM setiap desa dengan proyeksi anggaran Dana Desa yang seharusnya diperoleh.

Secara umum akan terdapat hubungan positif antara kebutuhan keuangan dengan upaya-upaya untuk meningkatkan status atau kondisi suatu desa. Dengan demikian maka seyogyanya desadesa atau kabupaten/kota dengan IDM yang lebih rendah patut diberikan kapasitas fiskal yang lebih besar untuk mengejar ketertinggalannya dibandingkan dengan daerah-daerah lain. Berkaca pada formula perhitungan Dana Alokasi Umum (DAU), apabila suatu daerah relatif lebih maju dan mampu mandiri dibandingkan dengan daerah lainnya, seharusnya daerah bersangkutan akan memerlukan bantuan pusat yang relatif lebih kecil. Daerah-daerah yang lebih maju pada umumnya akan memiliki sumber pendapatan desa yang relatif besar.

b. Perbandingan Alokasi Dana Desa dengan Rasio Jumlah Penduduk Miskin

Dana Desa diharapkan mampu mengakselerasi pembangunan di desa dan memacu pertumbuhan desa bersangkutan sehingga mendorong penduduk desa untuk keluar dari kemiskinan serta dapat memberikan multiplier effect ke wilayah di atasnya. Pola hubungan tersebut seharusnya dapat tergambarkan dalam penentuan alokasi Dana Desa. Saat ini sesuai dengan Peraturan
Pemerintah Nomor 22 tahun 2015, dalam alokasi formula Dana Desa untuk jumlah penduduk miskin diberikan pembobotan sebesar 35\%.

\section{Tabel 6. Perbandingan Dana Desa dengan Rasio Jumlah Penduduk Miskin}

\begin{tabular}{|c|c|c|c|}
\hline Uraian & $\begin{array}{c}\text { Tidore } \\
\text { Kepulauan }\end{array}$ & $\begin{array}{c}\text { Halmahera } \\
\text { Utara }\end{array}$ & $\begin{array}{c}\text { Halmahera } \\
\text { Barat }\end{array}$ \\
\hline Nama Desa & Selamalofo & Supu & Bataka \\
\hline Jumlah Penduduk & 614 & 1291 & 1316 \\
\hline $\begin{array}{l}\text { Jumlah Penduduk } \\
\text { Miskin }\end{array}$ & 155 & 485 & 696 \\
\hline Luas Wilayah & 141,39 & 31,06 & 0,55 \\
\hline $\begin{array}{l}\text { Indeks Kesulitas } \\
\text { Geografis }\end{array}$ & 69,7 & 53,1 & 46,96 \\
\hline Alokasi formula & 202.753 .988 & 82.227 .676 & 99.562 .520 \\
\hline
\end{tabular}

Sumber: Peraturan Bupati/Walikota Tahun 2016

Apabila dibandingkan antara desa yang memiliki rasio jumlah penduduk miskin terbesar di masing-masing kabupaten/kota terlihat bahwa Desa Selamalofo di Kota Tidore Kepulauan dengan jumlah penduduk miskin 155 orang memperoleh alokasi formula Dana Desa Tahun 2016 sebesar Rp203 juta, sedangkan Desa Supu di Kabupaten Halmahera Utara dan Desa Bataka di Halmahera Barat dengan jumlah penduduk miskin masingmasing 485 dan 696 memperoleh alokasi formula sebesar Rp82 juta dan Rp99 juta. Jika dilihat profilnya, Desa Selamalofo memiliki jumlah penduduk miskin lebih kecil dibandingkan jumlah penduduk miskin di dua desa yang lain namun memiliki luas wilayah yang jauh lebih luas. Selain itu IKG di Desa Selamalofo juga lebih besar dibandingkan desa yang lain. Berdasarkan profil desa tersebut menunjukkan bahwa luas wilayah desa meskipun hanya diberi bobot $10 \%$ dari alokasi formula namun cukup mempengaruhi alokasi formula Dana Desa yang diperoleh masingmasing desa.

\subsection{Analisis Penyaluran Dana Desa}

a. Penyaluran dari RKUN ke RKUD

Penyaluran Dana Desa dari RKUN ke RKUD untuk TA 2015 dilakukan melalui 3 (tiga) tahapan, yaitu tahap I paling lambat minggu kedua April sebesar $40 \%$, tahap II paling lambat minggu kedua Agustus sebesar $40 \%$, dan tahap III paling lambat minggu kedua Oktober sebesar 20\%.

\section{Tabel 7.Penyaluran Dana Desa dari RKUN ke RKUD Tahun Anggaran 2015}

(Dalam Miliar Rupiah)

\begin{tabular}{|lrrrrr|}
\hline Kab/Kota & Mei & Jul & \multicolumn{1}{c}{ Agt } & \multicolumn{1}{c}{ Des } & Total \\
\hline Tidore & 5,75 & 5.75 & - & 2,87 & 14,36 \\
\hline Halut & 21,01 & - & 21,01 & 10,51 & 52,53 \\
\hline Halbar & 18,13 & 18,13 & - & 9,07 & 45,33 \\
\hline Sumber: DJPK $(2016)$ & & & &
\end{tabular}

Tahap I penyaluran Dana Desa dari RKUN ke RKUD semuanya dilakukan pada Mei 2015. Hal ini berarti penyaluran Dana Desa pada ketiga daerah ini mengalami keterlambatan rata-rata 1 bulan 
sejak batas akhir penyaluran pada April 2015. Berdasarkan data yang diperoleh, keterlambatan penyaluran Dana Desa tahap I pada ketiga daerah tersebut lebih disebabkan karena keterlambatan dalam penetapan peraturan bupati/walikota mengenai tata cara pembagian dan penetapan rincian Dana Desa setiap desa. Sebagai contoh pada Kabupaten Halmahera Barat penetapan peraturan bupati/walikota mengenai tata cara pembagian dan penetapan rincian Dana Desa setiap desa baru dilakukan pada tanggal $18 \mathrm{Mei}$ 2015

\section{Tabel 8. Pemenuhan Persyaratan Penyaluran Dana Desa Tahap I Tahun Anggaran 2015}

\begin{tabular}{|l|l|c|}
\hline \multicolumn{1}{|c|}{\begin{tabular}{c}
\multicolumn{1}{c|}{ Uraian } \\
Halut
\end{tabular}} & $\begin{array}{c}\text { Ketepatan } \\
\text { Waktu }\end{array}$ \\
\hline & $\begin{array}{l}\text { Perda mengenai APBD tahun } \\
\text { anggaran berjalan }\end{array}$ & Ya \\
\hline - $\begin{array}{l}\text { Perbup mengenai tata cara } \\
\text { pembagian dan penetapan rincian } \\
\text { Dana Desa setiap Desa }\end{array}$ & Tidak \\
\hline Halbar & $\begin{array}{l}\text { peraturan daerah mengenai APBD } \\
\text { tahun anggaran berjalan }\end{array}$ & Ya \\
& $\begin{array}{l}\text { peraturan bupati/walikota } \\
\text { mengenai tata cara pembagian } \\
\text { dan penetapan rincian Dana Desa } \\
\text { setiap Desa }\end{array}$ & Tidak \\
\hline Tikep & $\begin{array}{l}\text { peraturan daerah mengenai APBD } \\
\text { tahun anggaran berjalan }\end{array}$ & Ya \\
\hline $\begin{array}{l}\text { peraturan bupati/walikota } \\
\text { mengenai tata cara pembagian } \\
\text { dan penetapan rincian Dana Desa } \\
\text { setiap Desa }\end{array}$ & Tidak \\
\hline Sumber: DPPKAD/BPKAD Masing-masing Pemda, (2015)
\end{tabular}

Keterlambatan penyaluran tahap I tersebut dapat menimbulkan berbagai risiko. Dari sisi ekonomi adalah munculnya opportunity loss yang ditanggung oleh daerah. Dana Desa yang seharusnya dapat diterima lebih awal menyebabkan implementasi program-program pembangunan dan pemberdayaan desa menjadi molor atau meleset dari rencana waktu yang telah ditetapkan, sehingga dari sisi waktu dan kesempatan terdapat kerugian. Dari sisi sosial adalah potensi timbulnya gejolak dan keresahan di tingkat desa khususnya bagi desa-desa yang telah melengkapi persyaratan penyaluran dengan tepat waktu. Namun, mereka belum dapat menerima kucuran dana sesuai jadwal. Selain itu yang tak kalah penting adalah dari sisi politis, keterlambatan penyaluran bisa saja menurunkan kredibilitas dan kepercayaan publik terhadap kinerja pemerintah daerah. Risiko tersebut dapat saja berulang pada tahun-tahun berikutnya apabila Pemda tidak melakukan manajemen risiko yang baik untuk menurunkan ataupun menghilangkan risiko dimaksud.

Penyaluran Dana Desa tahap II TA 2015 umumnya telah mengikuti norma waktu yaitu paling lambat minggu kedua bulan Agustus 2015.
Penyaluran Dana Desa tahap II pada Kabupaten Halmahera Barat dan Kota Tidore Kepulauan dilakukan pada Juli 2015 sementara Halmahera Utara dilakukan pada Agustus 2015. Persyaratan untuk penyaluran tahap II ini relatif lebih mudah dibandingkan tahap I karena yang diperlukan adalah penyampaian laporan penyaluran dan penggunaan Dana Desa tahap I. Laporan tersebut menunjukkan paling kurang Dana Desa tahap I telah disalurkan sebesar 50\% dari RKUD ke RKD. Berdasarkan data yang diperoleh, masing-masing daerah telah menyalurkan Dana Desa tahap I dari RKUD ke RKD rata-rata di atas 50\%.

Penyaluran Dana Desa tahap III dari RKUN ke RKUD untuk semua daerah observasi dilakukan pada Desember 2015 atau terlambat 2 (dua) bulan dari jadwal yang ditetapkan. Penyebab utama keterlambatan penyaluran tersebut adalah karena masing-masing daerah terlambat menyampaikan laporan penyaluran dan penggunaan Dana Desa tahap I dan tahap II. Apabila ditelusuri lebih jauh maka keterlambatan tersebut disebabkan oleh keterlambatan desa dalam menyampaikan laporan penggunaan Dana Desa tahap I sehingga berdampak pada terlambatnya penyaluran Dana Desa tahap II dari RKUD ke RKD.

Salah satu contoh, Kota Tidore Kepulauan baru melakukan transfer Dana Desa tahap II dari RKUD ke RKD dalam rentang Bulan September hingga Desember 2015 sehingga konsekuensinya adalah keterlambatan dalam menyusun laporan penyaluran yang dimaksud. Dari 3 desa yang diobservasi terkait penyampaian laporan penggunaan Dana Desa tahap I yaitu Desa Maitara, Maitara Tengah, dan Maitara Utara didapatkan temuan bahwa penyampaian laporan penggunaan Dana Desa oleh Desa Maitara baru dilakukan pada bulan Desember 2015, Desa Maitara Tengah pada bulan September 2015, dan Desa Maitara Utara pada bulan Desember 2015. Kondisi yang hampir sama juga ditemukan pada Kabupaten Halmahera Utara dan Halmahera Barat.

Risiko yang ditimbulkan dari keterlambatan penyaluran tahap III ini adalah terganggunya kelancaran eksekusi program-program Dana Desa. Penyaluran tahap III yang terjadi pada Desember 2015 akan menyebabkan kurangnya waktu untuk segera merealisasikan peruntukan Dana Desa dan mepetnya waktu yang tersedia untuk mempersiapkan laporan penggunaan dan pertanggungjawaban Dana Desa khususnya bagi perangkat desa.

\section{b. Penyaluran dari RKUD ke RKD}

Keterlambatan penyaluran Dana Desa yang diterima RKUD dari RKUN berdampak pada keterlambatan penyaluran Dana Desa dari RKUD 
ke RKD. Pemda belum sepenuhnya memenuhi norma waktu penyaluran Dana Desa dari RKUD ke RKD yaitu paling lambat 7 (tujuh) hari kerja sejak Dana Desa diterima di RKUD. Sebagai contoh untuk Kota Tidore Kepulauan, penyaluran Dana Desa diterima di RKUD per tanggal 7 Mei 2015. Sesuai norma waktu penyaluran, maka seharusnya paling lambat per tanggal 19 Mei 2015 Dana Desa sudah ditransfer ke RKD.

\section{Tabel 9.Penyaluran Dana Desa Tahap I Tahun 2015 dari RKUD ke RKD Desa Observasi Kota Tidore Kepulauan}

(dalam Jutaan Rupiah)

\begin{tabular}{|c|c|c|}
\hline \multirow{2}{*}{ Desa } & \multicolumn{2}{|c|}{ Penyaluran RKUD ke RKD } \\
\hline & Tanggal & Jumlah \\
\hline Maitara & 08-Jun-15 & 110,99 \\
\hline Maitara Utara & 08-Jun-15 & 112,99 \\
\hline Maitara Selatan & 08-Jun-15 & 113,22 \\
\hline
\end{tabular}

Dari hasil uji petik yang dilakukan pada 3 (tiga) Desa sebagaimana ditunjukkan pada tabel 9 diperoleh informasi bahwa penyaluran dilakukan pada tanggal 8 Juni 2015. Keterlambatan dari batas waktu yang ditetapkan ini disebabkan karena keterlambatan desa dalam menetapkan Peraturan Desa tentang Anggaran Pendapatan dan Belanja Desa. Salah satunya yang terjadi pada Desa Maitara Tengah yang baru menetapkan peraturan desa pada tanggal 25 Mei 2015, padahal berdasarkan ketentuan Peraturan Menteri Keuangan Nomor 247/PMK.07/2015 dinyatakan bahwa penyampaian peraturan desa tersebut paling lambat minggu kedua Maret 2015. Kesiapan dan kesanggupan perangkat desa dalam memenuhi persyaratan menjadi faktor utama penyebab keterlambatan penyaluran tahap I.

Permasalahan penyaluran Dana Desa tahap I dari RKUD ke RKD yang terjadi di Tidore Kepulauan juga ditemui di Halmahera Utara dan Halmahera Barat. Pada Halmahera Barat misalnya, penyaluran Dana Desa tahap I dari RKUD ke RKD rata-rata terjadi pada Agustus 2015. Keterlambatan tersebut juga disebabkan faktor kesiapan dan kesanggupan perangkat desa dalam menetapkan peraturan desa tentang APBDes secara tepat waktu. Uji petik yang dilakukan pada Desa Bobanehena didapatkan informasi bahwa peraturan desa tentang APBDes 2015 baru ditetapkan pada tanggal 5 Agustus 2015.

Dari fakta penyaluran tahap I tersebut dapat dipastikan bahwa pengerjaan program-program Dana Desa di tingkat desa baru terealisasi dan menumpuk pada semester II 2015. Keterlambatan penyaluran ini juga akan berimbas pada molornya pelaporan penggunaan Dana Desa tahap I yang akan disampaikan sebagai persyaratan penyaluran Dana Desa tahap II. Sementara itu, dampak negatif atas tidak terpenuhinya kewajiban Pemda untuk mentransfer Dana Desa dari RKUD ke RKD paling lambat 7 (tujuh) hari kerja sejak dana diterima di RKUD menyebabkan adanya dana pemerintah pusat yang mengendap lama di RKUD. Pengendapan dana di rekening pemda ini tidak produktif. Apabila dilihat dari sisi pengelolaan kas pemerintah pusat seharusnya dana tersebut dapat digunakan terlebih dahulu untuk membiayai program-program APBN yang mendesak atau untuk optimalisasi remunerasi pengelolaan rekening pemerintah pusat.

Penyaluran Dana Desa tahap II dari RKUD ke RKD juga mengalami keterlambatan. Penerimaan Dana Desa tahap II yang diterima RKUD pada tanggal 31 Juli 2015, tetapi jarak waktu sampai dengan ditransfer ke RKD mencapai 4-5 bulan. Jarak waktu tersebut tergolong cukup lama dan tidak produktif dari sisi pengelolaan rekening.

Tabel 10.Penyaluran Dana Desa Tahap II Tahun 2015 dari RKUD ke RKD Desa Observasi Kota Tidore Kepulauan

(Dalam Jutaan Rupiah)

\begin{tabular}{|c|c|c|}
\hline \multirow{2}{*}{ Desa } & \multicolumn{2}{|c|}{ Penyaluran RKUD ke RKD } \\
\hline & Tanggal & Jumlah \\
\hline Maitara & 15-Des-15 & 110,99 \\
\hline Maitara Utara & 10-Des-15 & 112,99 \\
\hline Maitara Selatan & 30-Nov-15 & 113,22 \\
\hline
\end{tabular}

Sumber: BPKAD Kota Tidore Kepulauan (2015)

Jika melihat kepada persyaratan penyaluran tahap II yaitu penyampaian laporan penggunaan Dana Desa tahap I (paling kurang Dana Desa tahap I telah digunakan sebesar 50\%), desa-desa yang menjadi obyek observasi pada Kota Tidore Kepulauan rata-rata terlambat dalam menyampaikan laporan dimaksud. Keterlambatan penyaluran Dana Desa pada tahap I memberi imbas pada molornya pelaksanaan kegiatan pembangunan dan pemberdayaan desa sehingga berdampak pada molornya pelaporan penggunaan Dana Desa tahap I.

Dampak atas keterlambatan penyaluran tahap II ini bagi Pemda ialah betapa mepetnya waktu yang dimiliki oleh Pemda untuk segera mempersiapkan laporan penggunaan Dana Desa tahap I dan tahap II sebagai persyaratan penyaluran tahap III dari RKUN ke RKUD. Sementara itu dampak bagi desa adalah risiko tidak terserapnya Dana Desa secara optimal serta risiko menumpuknya kegiatan di akhir tahun sehingga berpengaruh terhadap kualitas penyelesaian proyek/kegiatan. Penyaluran Dana Desa tahap III dari RKUD ke RKD untuk semua Pemda yang diobservasi dilakukan pada bulan 
Desember 2015 atau terlambat 2 (dua) bulan dari jadwal yang ditetapkan.

\section{Tabel 11.Penyaluran Dana Desa Tahap III Tahun 2015 dari RKUD ke RKD Desa Observasi Kota Tidore Kepulauan}

(Dalam Jutaan Rupiah)

\begin{tabular}{|l|r|r|}
\multirow{2}{*}{ Desa } & \multicolumn{2}{|c}{ Penyaluran RKUD ke RKD } \\
& Tanggal & \multicolumn{1}{c}{ Jumlah } \\
\hline Maitara & 23-Des-15 & 55,50 \\
\hline Maitara Utara & 23-Des-15 & 56,50 \\
\hline Maitara Selatan & 23-Des-15 & 56,61 \\
\hline
\end{tabular}

Sumber: BPKAD Kota Tidore Kepulauan (2015)

Penyaluran tahap III Dana Desa Kota Tidore Kepulauan kepada desa-desa yang menjadi obyek observasi dilakukan pada tanggal 23 Desember 2015 menjelang akhir tahun. Penyebab utama keterlambatan penyaluran tersebut adalah karena masing-masing desa terlambat menyampaikan laporan penggunaan Dana Desa tahap I dan tahap II. Kondisi keterlambatan ini merupakan muara atas keterlambatan penyaluran yang terjadi pada tahap I dan tahap II. Dampak keterlambatan bagi desa adalah risiko tidak terserapnya Dana Desa secara optimal serta risiko menumpuknya kegiatan di akhir tahun sehingga berpengaruh terhadap kualitas penyelesaian proyek/kegiatan.

\subsection{Analisis Ketepatan Penggunaan Dana Desa}

Pada tahun 2015, Dana Desa diprioritaskan untuk membiayai belanja bidang pelaksanaan pembangunan dan pemberdayaan masyarakat desa. Prioritas penggunaan Dana Desa untuk pembangunan desa dialokasikan untuk mencapai tujuan pembangunan desa yaitu meningkatkan kesejahteraan masyarakat desa dan kualitas hidup manusia serta penanggulangan kemiskinan melalui: (1) pemenuhan kebutuhan dasar; (2) pembangunan sarana dan prasarana desa; (3) pengembangan potensi ekonomi lokal desa; (4) pemanfaatan sumber daya alam dan lingkungan secara berkelanjutan. Prioritas penggunaan Dana Desa untuk pemberdayaan masyarakat diutamakan untuk penanggulangan kemiskinan dan peningkatan akses atas sumber daya ekonomi.

\section{Grafik 1. Alokasi Penggunaan Dana Desa (DD) \& Alokasi Dana Desa (ADD) pada Bidang-Bidang di Desa Observasi Th 2015}

(Dalam Jutaan Rupiah)

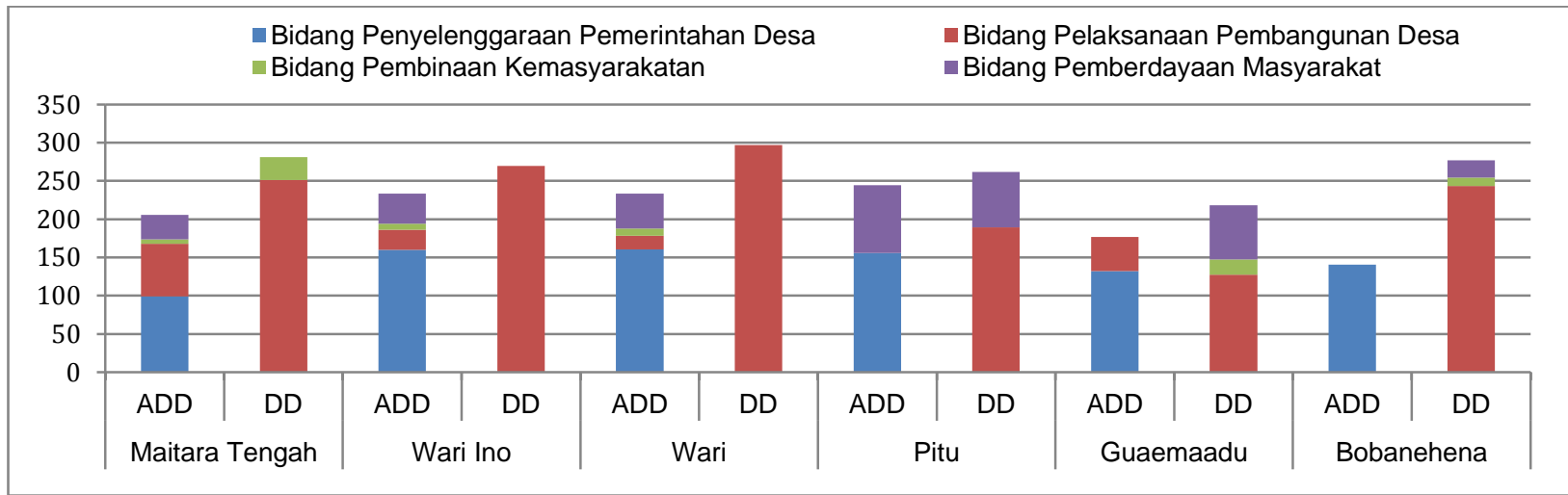

Sumber: Rincian APBDes Desa Observasi Tahun 2015 (data diolah)

Berdasarkan grafik 1, penggunaan Dana Desa tahun 2015 pada desa observasi paling dominan digunakan untuk bidang pelaksanaan pembangunan desa dengan rata-rata $86 \%$, sisanya $10 \%$ digunakan untuk bidang pemberdayaan masyarakat, $4 \%$ untuk bidang pembinaan kemasyarakatan. Dari Alokasi Dana Desa (ADD) di desa observasi, rata-rata $69 \%$ digunakan untuk bidang penyelenggaraan pemerintahan desa, 13\% untuk bidang pelaksanaan pembangunan desa, $2 \%$ untuk bidang pembinaaan kemasyarakatan, serta $17 \%$ untuk bidang pemberdayaan masyarakat.

Pola di atas menggambarkan pola ketepatan penggunaan Dana Desa secara umum, yang menyiratkan bahwa desa observasi telah menggunakan Dana Desa untuk pelaksanaan pembangunan desa maupun pemberdayaan masyarakat. Penggunaan dana yang sesuai dengan prioritas penggunaan Dana Desa tahun 2015. Penggunaan yang telah sesuai prioritas tersebut bervariasi mulai dari: (1) pelaksanaan pembangunan untuk pemenuhan kebutuhan dasar berupa pembangunan posyandu, polindes, dan PAUD; (2) pembangunan sarana prasarana desa berupa pembangunan badan jalan desa, jalan setapak, rabat beton, deker, drainase, dan pengadaan air bersih; (3) pembangunan untuk pengembangan potensi ekonomi lokal berupa pendirian BUMDesa atau Koperasi. 
Di sisi lain terdapat beberapa penggunaan Dana Desa yang kurang sesuai ketentuan yaitu: (1) pembangunan kantor desa, dan; (2) pembangunan pos pelabuhan. Pembangunan kantor desa kurang sesuai dengan prioritas penggunaan Dana Desa karena lebih tepat diklasifikasikan dalam bidang penyelenggaraan pemerintahan desa yang seharusnya dibiayai dari Alokasi Dana Desa (ADD). Kondisi kantor desa yang telah rusak menyebabkan kurang berjalannya administrasi pemerintahan sehingga pembangunannya menjadi prioritas desa bersangkutan. Di lain pihak, pembiayaan dari ADD maupun sumber lain belum mampu mencukupi kebutuhan tersebut.

Beberapa kegiatan pemberdayaan masyarakat di desa observasi telah sesuai dengan prioritas penanggulangan kemiskinan dan peningkatan akses atas sumber daya ekonomi. Kegiatan tersebut berupa pemberdayaan kesejahteraan keluarga dan peningkatan kelompok usaha kerajinan mebel karang taruna. Di sisi lain terdapat kegiatan pemberdayaan yang kurang sesuai dengan prioritas penggunaan Dana Desa seperti: (1) kegiatan pelatihan perangkat desa, dan; (2) penunjang kegiatan keagamaan, posyandu, dan karang taruna.

Penyebab tidak selarasnya prioritas penggunaan Dana Desa dapat terjadi karena bias penerjemahan dua regulasi yang berbeda. Permendes memberikan rambu-rambu bahwa prioritas Dana Desa digunakan dalam rangka pelaksanaan pembangunan dan pemberdayaan masyarakat desa. Sementara Permendagri memberikan ketentuan bahwa sepanjang pelaksanaan program telah melalui perencanaan/musyawarah dan tertuang dalam APBDesa maka hal tersebut menjadi sah. Hal inilah yang kemudian menjadi dasar bagi desa maupun kabupaten/kota untuk memutuskan penggunaan Dana Desa dalam rangka pembangunan kantor desa karena dinilai sebagai prioritas.

Bila dibandingkan dengan tahun 2015, pola penggunaan Dana Desa tahun 2016 pada desa observasi masih tetap mengarah pada bidang pelaksanaan pembangunan desa dengan rata-rata $86 \%$, sisanya $13 \%$ untuk bidang pemberdayaan masyarakat, serta $1 \%$ untuk bidang pembinaan kemasyarakatan.

\section{Grafik 2. Alokasi Penggunaan Dana Desa (DD) \& Alokasi Dana Desa (ADD) pada Bidang-Bidang di Desa Observasi Th 2016}

(Dalam Jutaan Rupiah)

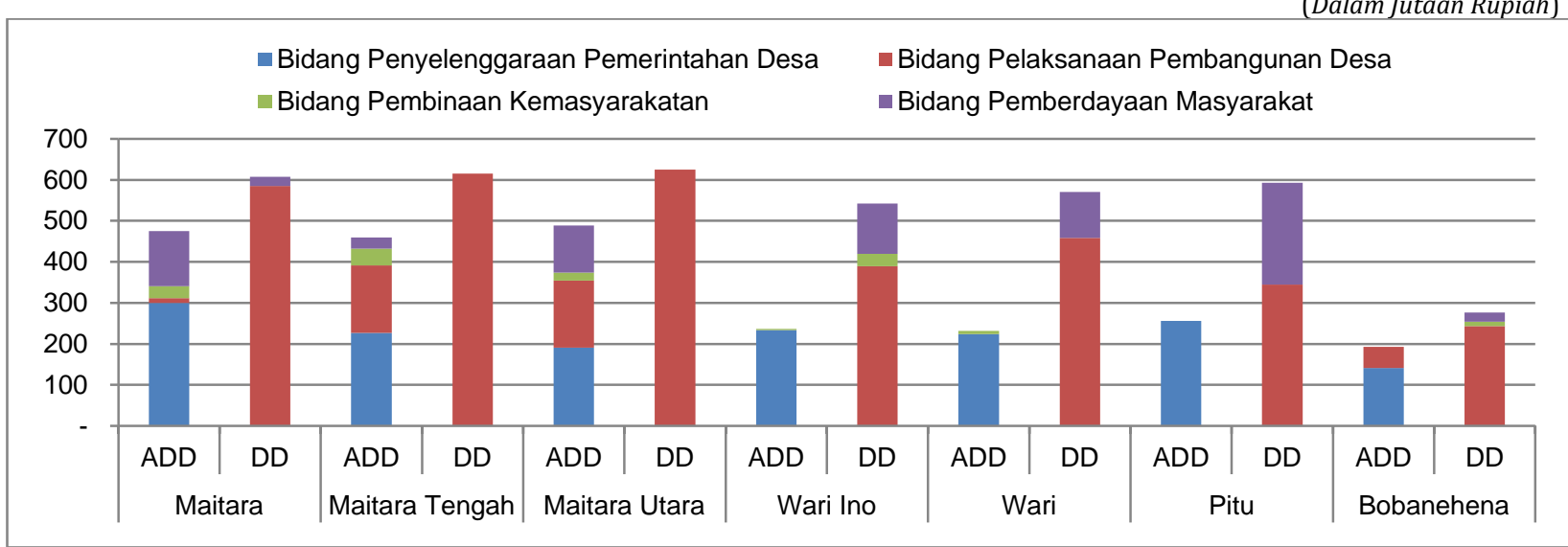

Sumber: Rincian APBDes Desa Observasi Tahun 2016 (data diolah)

Pola penggunaan Dana Desa tahun 2016 pada desa observasi masih tetap mengarah pada bidang pelaksanaan pembangunan desa dengan rata-rata $86 \%$, sisanya $13 \%$ untuk bidang pemberdayaan masyarakat meningkat dibandingkan tahun 2015 yang mencapai $10 \%$, serta $1 \%$ untuk bidang pembinaan kemasyarakatan. Jika dilihat dari pola penggunaan ADD di desa observasi, pada tahun 2016 secara rata-rata 67\% digunakan untuk bidang penyelenggaraan pemerintahan desa, $17 \%$ untuk bidang pelaksanaan pembangunan, 4\% untuk bidang pembinaan kemasyarakatan, serta $12 \%$ untuk bidang pemberdayaan masyarakat. Bila dibandingkan tahun 2015, pola ADD cenderung digunakan untuk mendukung bidang pelaksanaan pembangunan. Jika di tahun sebelumnya bidang pemberdayaan masyarakat mengandalkan dari ADD maka di tahun 2016 mulai menggunakan pendanaan dari Dana Desa. Hal ini terjadi seiring dengan meningkatnya besaran alokasi Dana Desa yang digelontorkan ke desa-desa di seluruh Indonesia.

Pada tahun 2016, prioritas penggunaan Dana Desa yang ditetapkan merupakan rambu-rambu yang bukan membatasi prakarsa lokal desa melainkan memberikan pandangan prioritas penggunaan. Kegiatan pelaksanaan pembangunan 


\section{Halaman 70}

di desa observasi yang bersumber dari Dana Desa cukup bervariasi mulai dari: (1) pembangunan sarana fisik untuk penghidupan berupa pembangunan jalan desa, drainase, tembok, deker, sumur bor; (2) pembangunan sarana prasarana pendidikan, sosial budaya berupa pembangunan gedung PAUD, gedung pembelajaran keagamaan; (3) pembangunan sarana ekonomi masyarakat berupa bangunan pariwisata, dan bangunan BUMDesa. Namun masih Terdapat kegiatan pelaksanaan pembangunan yang dinilai kurang tepat dari sisi penggunaan Dana Desa seperti: (1) pembebasan lahan TPU desa; (2) pembangunan sarana kompleks kuburan, serta (3) pembuatan gapura desa dengan kisaran porsi $16-23 \%$. Namun demikian, jika dibandingkan dengan tahun 2015, terdapat arah perbaikan dalam ketepatan penggunaan Dana Desa. Jika pada tahun 2015 persentase Dana Desa yang digunakan kurang sesuai peruntukannya mencapai $59-65 \%$ maka pada tahun 2016 menurun dengan kisaran 16$23 \%$. Pada tahun 2016, pertimbangan mengenai tipologi desa juga digunakan dalam rangka menentukan prioritas penggunaan Dana Desa. Tipologi desa disusun berdasarkan kekerabatan desa, hamparan, pola permukiman, mata pencaharian, serta tingkat perkembangan kemajuan desa. Khusus mengenai tipologi desa berdasarkan tingkat perkembangan kemajuan desa, status desa dapat digunakan untuk menentukan prioritas penggunaan Dana Desa.

\section{Grafik 3. Pola Penggunaan Dana Desa Bidang Pembangunan Desa Berdasarkan Status Kemajuan Desa} Observasi Tahun 2016

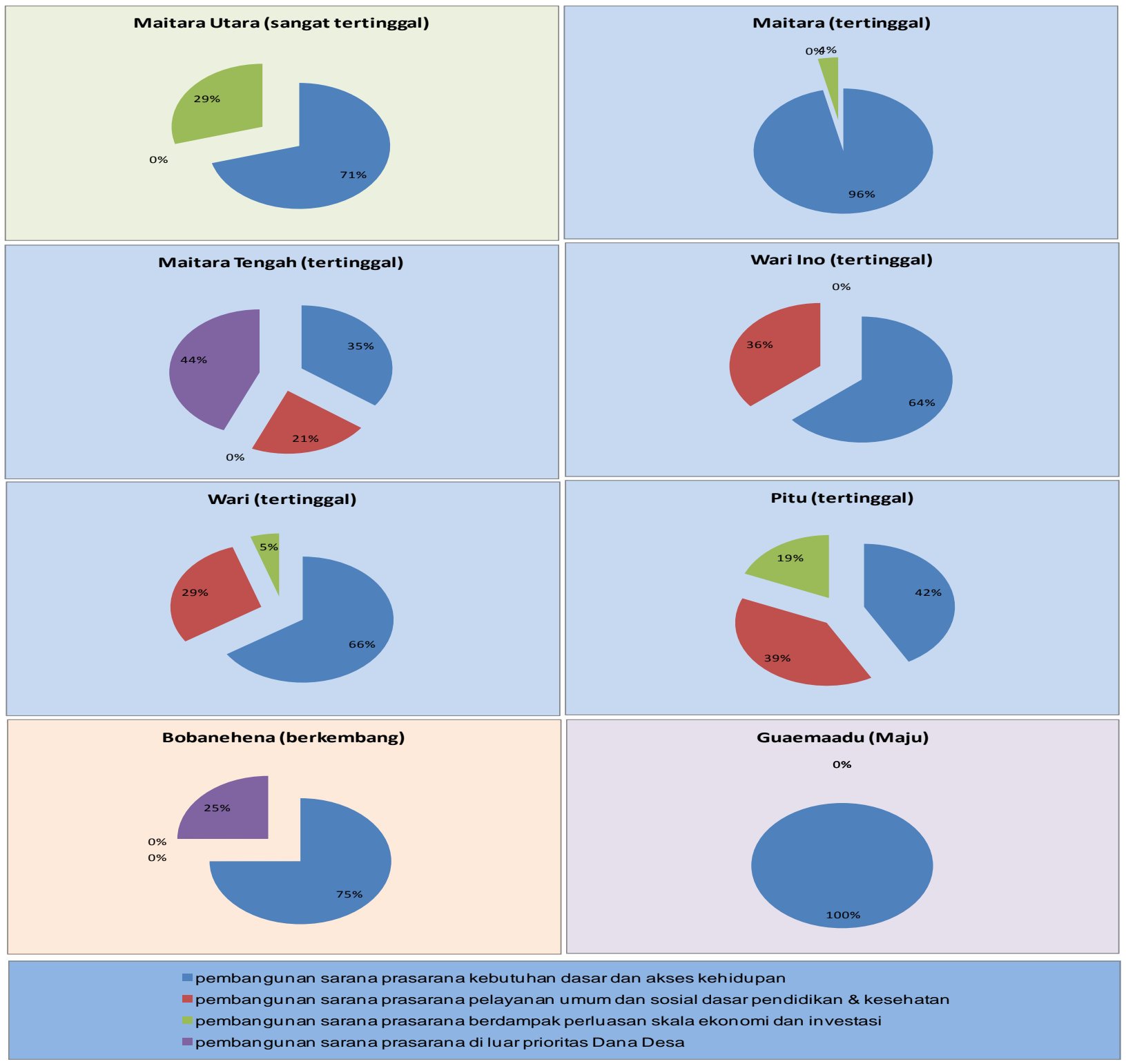


Berdasarkan pelaksanaan pembangunan fisik, rata-rata desa tertinggal/sangat tertinggal secara dominan melaksanakan pembangunan yang cukup imbang antara sarana prasarana kebutuhan dasar dan akses penghidupan dengan sarana prasarana pelayanan umum dan sosial dasar pendidikan dan kesehatan. Beberapa desa tertinggal/sangat tertinggal juga sudah mengarahkan pembangunannya untuk sarana prasarana yang berdampak pada perluasan skala ekonomi dan investasi berupa pembangunan sarana pariwisata serta pembangunan BUMDes dengan kisaran 4\% sampai dengan 29\%. Menurut rambu-rambu prioritas penggunaan Dana Desa tahun 2016, desa dengan status tertinggal/sangat tertinggal perlu mengutamakan pembangunan sarana prasarana kebutuhan dasar dan akses penghidupan, namun demikian pola yang ada menunjukkan bahwa desa tertinggal/sangat tertinggal tidak hanya menggunakan Dana Desa untuk keperluan tersebut.

Beberapa kebijakan perlu diambil misalnya: (1) mempertegas rambu-rambu bahwa untuk desa tertinggal/sangat tertinggal, Dana Desa hanya diperuntukkan bagi pembangunan sarana prasarana kebutuhan dasar dan akses penghidupan sementara pembangunan sarana lainnya menggunakan sumber dana selain Dana Desa; (2) untuk desa tertinggal/sangat tertinggal dapat menggunakan Dana Desa untuk pembangunan sarana prasarana secara pararel namun tetap harus memperhatikan prioritas tertinggi bagi pemenuhan sarana prasarana kebutuhan dasar dan akses penghidupan masyarakat.

Pola yang terjadi pada desa berkembang menunjukkan bahwa Dana Desa masih digunakan untuk pembangunan sarana prasarana kebutuhan dasar mencapai $75 \%$ dibandingkan dengan rambu-rambunya yang menghendaki penggunaan Dana Desa untuk pembangunan sarana prasarana pelayanan umum dan sosial dasar pendidikan \& kesehatan. Sementara itu di desa maju, Dana Desa digunakan untuk pembangunan sarana prasarana kebutuhan dasar yang kurang sesuai dengan rambu-rambunya yang menghendaki penggunaan Dana Desa untuk pembangunan sarana prasarana yang berdampak pada perluasan skala ekonomi dan investasi desa.

Rata-rata alokasi Dana Desa untuk bidang pemberdayaan masyarakat pada sembilan desa observasi mencapai $14 \%$. Desa dalam kategori sangat tertinggal seperti Desa Ulo dan Desa Maitara Utara tidak menganggarkan Dana Desa untuk bidang pemberdayaan Masyarakat. Alokasi untuk bidang pemberdayaan masyarakat pada desa di wilayah Halmahera Utara relatif besar dengan alokasi terbesar berada pada Desa Pitu yang mencapai $41,84 \%$.

Di bidang pemberdayaan masyarakat, beberapa desa observasi berklasifikasi tertinggal menggunakan Dana Desa dengan alokasi tertinggi untuk kegiatan pelatihan atau peningkatan kapasitas kepala desa dan perangkat desa (termasuk BPD). Apabila ditelusuri lebih jauh kegiatan pelatihan kepala desa dan perangkat desa digunakan untuk alokasi perjalanan dinas. Kegiatan pelatihan Kepala Desa dan Perangkat Desa merupakan kegiatan dalam rangka meningkatkan kualitas proses perencanaan desa dan peningkatan kapasitas kader pemberdayaan masyarakat. Kegiatan tersebut merupakan prioritas penggunaan Dana Desa untuk pemberdayaan masyarakat desa tahun 2015 sesuai dengan Permendes Nomor 5 Tahun 2015 namun tidak menjadi prioritas untuk tahun 2016.

Sesuai dengan Permendes Nomor 21 Tahun 2015, prioritas penggunaan Dana Desa bidang pemberdayaan masyarakat tahun 2016 untuk desa tertinggal mengutamakan kegiatan pemberdayaan masyarakat yang beriorientasi pada membuka lapangan kerja dan atau usaha baru, serta bantuan penyiapan infrastruktur bagi terselenggaranya kerja dan usaha warga atau masyarakat dari proses produksi sampai pemasaran produk, serta pemenuhan kebutuhan atau akses kehidupan masyarakat. Dana Desa akan menjadi lebih bermanfaat apabila fokus kegiatan pemberdayaan pada peningkatan kapasitas masyarakat desa bukan peningkatan kapasitas pemerintah desa. Pemerintah desa seharusnya bisa merancang kegiatan pelatihan wirausaha, manajemen usaha BUMdes, pelatihan membuat kerajinan ataupun jika ingin meningkatkan kapasitas pemerintah desa, pelatihannya dapat dilaksanakan di desa setempat atau di ibukota kabupaten yang relatif lebih hemat.

Kegiatan yang hampir terdapat pada seluruh sampel desa observasi adalah Kegiatan PKK dan Kegiatan Posyandu. Kegiatan PKK dan Kegiatan Posyandu dapat dikategorikan sebagai kegiatan prioritas penggunaan Dana Desa tahun 2016 apabila berbentuk kegiatan promosi dan edukasi kesehatan masyarakat serta gerakan hidup bersih dan sehat sesuai dengan Pasal 8 Permendes Nomor 21 Tahun 2015. Kegiatan Lomba PKK tidak berkorelasi secara langsung dengan kegiatan promosi dan edukasi kesehatan masyarakat sehingga seharusnya tidak dapat dikategorikan sebagai bidang Pemberdayaan Kemasyarakatan, lebih tepat apabila dialokasikan dalam bidang Pembinaan Kemasyarakatan. Sesuai dengan pedoman umum prioritas penggunaan Dana Desa tahun 2016 sebagaimana terdapat dalam 
Lampiran Permendes Nomor 21 Tahun 2015, program atau kegiatan selain pada bidang pembangunan desa dan pemberdayaan masyarakat desa pendanaannya bersumber pada APBD seperti Alokasi Dana Desa (ADD) sehingga lomba kegiatan PKK seharusnya tidak menggunakan Dana Desa. Pemberian Insentif/honor dan seragam kader posyandu lebih mendominasi alokasi anggaran penunjang kegiatan posyandu dibandingkan alokasi untuk inventaris posyandu dan makanan tambahan bayi. Kegiatan posyandu akan lebih bermanfaat apabila digunakan untuk kegiatan sosialisasi pencegahan penyakit malaria, demam berdarah dan sebagainya.

Praktek mengalokasikan insentif/honor juga terdapat pada kegiatan Lembaga Pemberdayaan Masyarakat di desa observasi. Selain itu terdapat alokasi yang kurang tepat yaitu penunjang kegiatan pemuda/karang taruna. Penunjang Kegiatan Pemuda/Karang Taruna digunakan sebagai penunjang kegiatan olahraga yaitu pembelian seragam olahraga. Akan menjadi lebih tepat sasaran jika digunakan untuk pelatihan wirausaha bagi pemuda, pelatihan pembibitan, ataupun menambah alokasi dana untuk kelompok sadar wisata, sanggar seni pemuda dan lainnya. Terlihat bahwa desa yang mengalokasikan pada kegiatan tersebut masih mengacu pada Prioritas Penggunaan Dana Desa Tahun 2015, pada pasal 11 Permendes Nomor 5 Tahun 2015, prioritas penggunaan Dana Desa tahun 2015 salah satunya untuk peningkatan kapasitas kelompok masyarakat antara lain kelompok pemuda. Sedangkan pada Permendes Nomor 21 Tahun 2015, prioritas penggunaan Dana Desa tahun 2016 untuk peningkatan kapasitas kelompok masyarakat tidak melihat pada jenis kelompok masyarakat melainkan dibatasi pada tujuannya yaitu ditujukan untuk energi terbarukan, pelestarian lingkungan hidup dan kegiatan pemberdayaan ekonomi lainnya.

Selain itu, terdapat kegiatan pemberdayaan yang berpotensi tumpang tindih dengan kegiatan yang dibiayai dari dana APBN/APBD yaitu pemberian beasiswa bagi anak sekolah (SD-SMP) sebanyak 40 siswa dengan alokasi sebesar 20 juta. Kegiatan tersebut tidak sesuai dengan prioritas penggunaan Dana Desa bidang pemberdayaan masyarakat dan juga berpotensi tumpang tindih dengan kegiatan Bantuan Siswa Miskin atau Program Indonesia Pintar yang dibiayai dari dana APBN. Dari uraian di atas terlihat bahwa penentuan kegiatan bidang pemberdayaan masyarakat yang dibiayai dari Dana Desa belum sesuai dengan kebutuhan desa, namun masih dilandasi oleh keinginan sehingga mendorong pembiayaan kegiatan yang bersifat konsumtif seperti pemberian insentif dan perjalanan dinas. Sosialisasi terhadap Permendes Nomor 21 Tahun 2015 belum berjalan baik, terbukti masih terdapat kegiatan yang yang tidak sesuai dengan prioritas penggunaan Dana Desa tahun 2016 melainkan masih mengacu pada prioritas penggunaan Dana Desa tahun 2015.

\subsection{Analisis Kesesuaian Penggunaan Dana Desa dengan Rencana}

Program/kegiatan yang terdapat pada APBDesa (yang dibiayai dari Dana Desa) telah direncanakan di dalam RKP Desa maupun RPJM Desa. Keterkaitan paling kuat terdapat pada APBDesa dengan RKP Desa. Sementara itu, keterkaitan antara RKP Desa dengan RPJM Desa memang telah terpenuhi, namun demikian perlu difokuskan kembali rencana yang tertuang dalam jangka menengah. Sebagai contoh, beberapa desa observasi memiliki rencana pembangunan jangka menengah yang menantang tetapi penjabaran dalam RKP tahunan dinilai kurang fokus karena terbatasnya dana yang ada. Beberapa desa observasi juga telah menentukan prioritas dengan memakai metode pembobotan namun karena keterbatasan dana menyebabkan Dana Desa digunakan untuk membiayai bidang selain pelaksanaan pembangunan dan pemberdayaan masyarakat desa. Sebagai contoh, berdasarkan pembobotan, pembangunan kantor kepala desa yang telah rusak menjadi salah satu prioritas utama namun kemudian menjadi kurang tepat karena dibiayai dari Dana Desa.

\subsection{Analisis Potensi Tumpang Tindih Pembiayaan}

Pada tahun 2015 dan 2016 secara umum tidak terdapat program yang mengalami tumpang tindih baik yang dibiayai dari Dana Desa maupun yang dibiayai dari APBD. Namun demikian beberapa pembangunan seperti poskedes, polindes, embung desa yang merupakan kewenangan berskala lokal desa dibiayai dengan APBD. Beberapa pokok persoalan yang dapat menyebabkan terjadinya potensi tumpang tindih pembiayaan program sebagai berikut:

1. Kewenangan desa dalam melaksanakan pembangunan telah jelas tertuang dalam hak asal usul dan kewenangan berskala lokal desa, namun karena masih terbatasnya sumber Dana Desa mengakibatkan adanya urusan desa yang dibiayai dari APBD;

2. Terdapat area abu-abu (grey area) dalam hal jenis kegiatan maupun lokasi pembangunan serupa yang dapat menyimpan potensi tumpang tindih pembiayaan jika tidak dilakukan koordinasi yang baik antar tingkat pemerintahan. 
Berdasarkan keterangan pihak kabupaten/ kota maupun pihak desa observasi, dinyatakan bahwa tidak terdapat kegiatan pembangunan yang tumpang tindih antar tingkat pemerintahan karena telah dilakukan mekanisme musrenbang maupun evaluasi penggunaan Dana Desa. Khusus mengenai evaluasi penggunaan Dana Desa, pemerintah kabupaten/kota melakukan proses evaluasi rancangan Perda APBDesa dengan poin evaluasi berupa: (1) Kelengkapan administrasi Raperda APBDesa; (2) Kepatuhan terhadap peraturan yang lebih tinggi; (3) Teknik penyusunan APBDesa; (4) Ketentuan belanja; (5) Daftar kegiatan yang menjadi prioritas penggunaan Dana Desa; (6) Kepastian bahwa seluruh kegiatan APBDesa telah tertuang dalam RKP Desa dan RPJM Desa. Pada akhirnya kegiatan pembangunan yang dibiayai oleh Dana Desa masih menyimpan potensi tumpang tindih di masa mendatang jika tidak dilakukan pemisahan kewenangan secara jelas serta pelaksanaan mekanisme koordinasi antar tingkatan pemerintahan.

\section{Grafik 4. Pagu dan Realisasi Penggunaan Dana Desa Tahun 2015}

(Dalam Jutaan Rupiah)

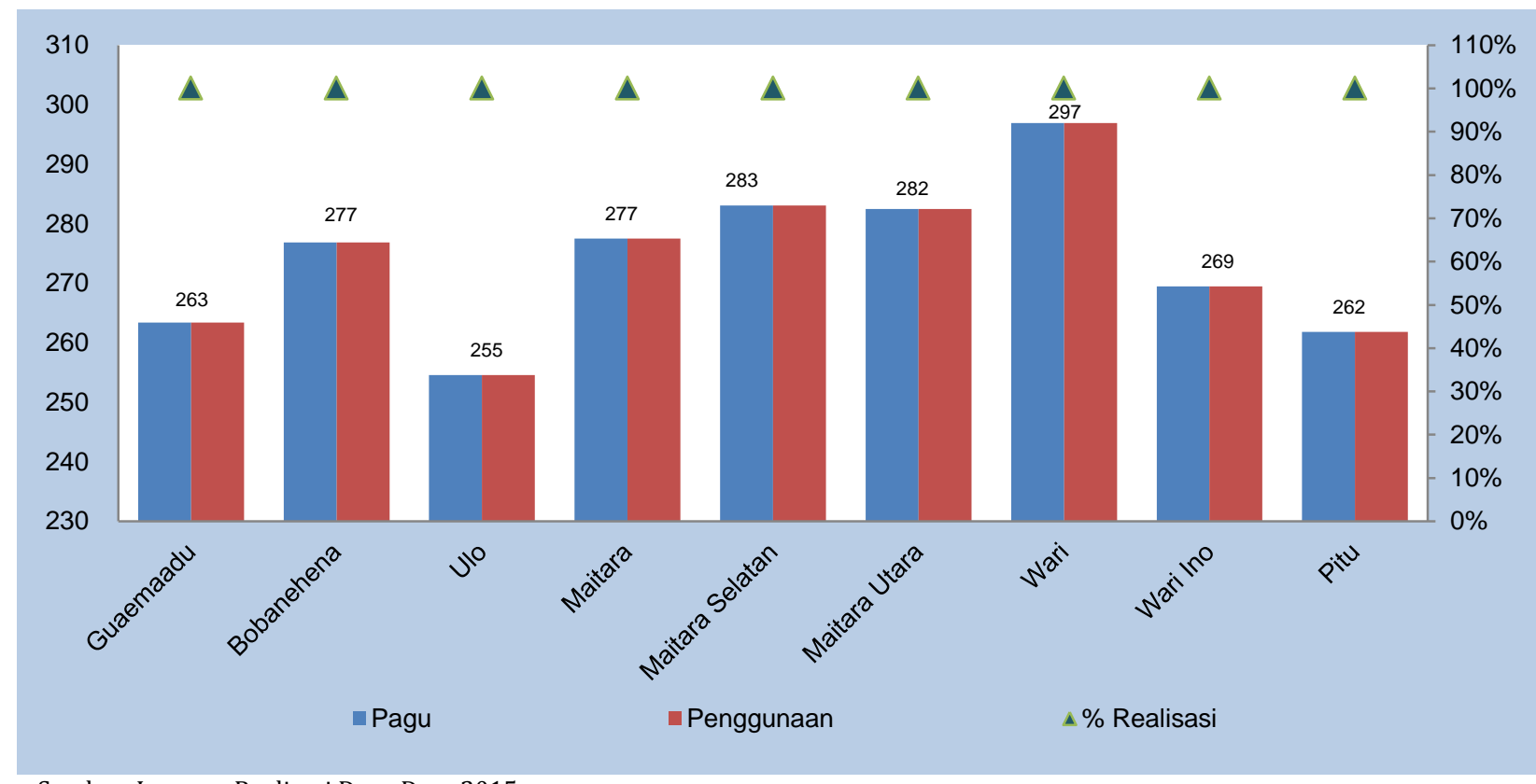

Sumber: Laporan Realisasi Dana Desa 2015

\subsection{Analisis Efisiensi dan Efektivitas Penggunaan Dana Desa}

Secara keseluruhan dari sembilan desa yang menjadi sampel observasi, Dana Desa tahun 2015 telah digunakan seluruhnya atau dengan kata lain realisasi penggunaan Dana Desa telah mencapai $100 \%$. Tingkat realisasi yang sudah mencapai $100 \%$ akan lebih bermanfaat bagi pembangunan perekonomian desa apabila pengelolaan Dana Desa dilakukan secara efisien dan efektif. Suatu kegiatan dikerjakan secara efisien jika pelaksanaan pekerjaan tersebut telah mencapai sasaran dengan biaya yang terendah atau dengan biaya minimal diperoleh hasil yang diinginkan. Secara sederhana, efisiensi melihat pada komponen input biaya yang digunakan. Penggunaan satuan standar biaya yang berlaku pada kabupaten menjadi relevan penggunaannya dalam menciptakan efisiensi biaya. Penggunaan standar biaya dapat dipakai untuk menilai kewajaran biaya dan menghindari penggunaan harga satuan yang melebihi standar biaya agar tercipta efisiensi biaya dalam penyusunan Rancangan Anggaran Biaya (RAB) dan pada akhirnya tercipta efisiensi saat pelaksanaan kegiatan.

Berdasarkan wawancara dengan pihak BPMPD Kabupaten/Kota Observasi, Kabupaten/Kota telah memiliki standar satuan harga yang ditetapkan berdasarkan Keputusan Kepala Daerah dan berlaku selama 1 (satu) tahun untuk digunakan sebagai pedoman yang digunakan SKPD dalam menyusun Rencana Kegiatan Anggaran (RKA) tiap tahunnya. Selanjutnya standar satuan harga tersebut diarahkan agar digunakan oleh pemerintah desa dalam menyusun RAB. Standar harga tersebut juga digunakan sebagai alat evaluasi oleh BPMPD dan DPKAD dalam mengevaluasi RAB dan RAPB Desa yang disusun oleh pemerintah desa. Pada prakteknya, berdasarkan hasil observasi di lapangan masih ditemukan adanya perbedaan harga satuan yang digunakan dalam penyusunan RAB antar satu desa dengan desa lainnya, 
walaupun desa tersebut berdekatan dan terletak dalam satu kecamatan.

\section{Tabel 12. Perbandingan Harga Satuan dalam Penyusunan RAB Saluran Air/Drainase} Tahun 2015

\begin{tabular}{|c|c|c|c|c|c|}
\hline $\begin{array}{l}\text { Item } \\
\text { Barang }\end{array}$ & $\begin{array}{c}\text { Maitara } \\
\text { Utara }\end{array}$ & Maitara & Selisih & Volume & Inefisiensi \\
\hline (1) & (2) & (3) & $\begin{array}{c}(4=2- \\
3)\end{array}$ & (5) & $(6=4 \times 5)$ \\
\hline Semen & 110.000 & 100.000 & 10.000 & 20 Sak & 200.000 \\
\hline Pasir & 458.000 & 375.000 & 83.000 & 6 Kubik & 498.000 \\
\hline Batu & 500.500 & 320.000 & 180.500 & 4 Kubik & 722.000 \\
\hline \multicolumn{5}{|c|}{ Jumlah Inefisiensi } & 1.420 .000 \\
\hline
\end{tabular}

Sumber: Diolah dari RAB-APBDes 2015

Dari data RAB Pembuatan Saluran Air/Drainase Tahun 2015 terdapat selisih harga satuan dimana harga satuan di desa observasi yang satu lebih murah dibandingkan desa observasi yang lain. Mengacu pada konsep efisiensi yaitu penggunaan biaya seminimal mungkin, maka seharusnya Pembuatan Saluran Air/Drainase dapat lebih efisien jika menggunakan harga yang lebih murah. Efisiensi yang tercipta sebesar 1.420 .000 untuk pembuatan saluran air/drainase. Efisiensi tersebut bisa digunakan untuk menambah panjang saluran air yang dibangun atau digunakan untuk keperluan pembangunan infrastruktur lainnya.

Berdasarkan kondisi tersebut, menandakan belum terdapat keseragaman harga satuan yang digunakan dan evaluasi atas RAPB Desa yang dilakukan oleh pihak BPMPD dan DPKAD belum optimal. Seharusnya evaluasi yang dilakukan juga membandingkan harga satuan antara satu desa dengan desa lainnya yang terletak dalam kecamatan yang sama untuk mencari harga satuan yang paling efisien. Dana Desa akan lebih memberikan manfaat dalam meningkatkan pembangunan infrastruktur perdesaan apabila digunakan secara efisien. Selain itu, pemahaman pemerintah desa dalam menyusun RAB yang benar masih minim terutama dalam menetapkan volume dan harga satuan. Seperti yang terlihat pada penyusunan RAB Pembuatan Jalan Setapak di salah satu desa observasi tahun 2016, terdapat kejanggalan dalam penentuan volume dan harga satuan untuk komponen Upah Tenaga Kerja, dengan harga satuan 1.000.000 dan volume 4 orang, total upah tenaga kerja sebesar 60.000.000.

Dari permasalahan di atas, terlihat bahwa pemahaman pemerintah desa dalam menyusun RAB dan penggunaan harga satuan belum memadai. Dinas Pekerjaan Umum Kabupaten/Kota dapat mengambil peranan dengan memberikan asistensi penyusunan RAB serta desain teknis pembangunan infrastruktur.
Peran dari tenaga pendamping desa juga perlu ditingkatkan dalam hal penyusunan RAB maupun lainnya. Berdasarkan wawancara dengan perangkat desa observasi, tenaga pendamping menangani 3 sampai dengan 5 desa, dengan kondisi geografis dari satu desa ke desa lainnya berjauhan, sehingga tenaga pendamping sering tidak ada di tempat. Peran tenaga pendamping menjadi kurang efektif. Pihak BPMPD menambahkan bahwa perekrutan tenaga pendamping secara terpusat seolah-olah menjadikan tenaga pendamping lepas dari pengawasan BPMPD Kabupaten/Kota. Pihak BPMPD tidak memiliki data tenaga pendamping yang berada dalam wilayah kabupaten/kota sehingga tidak dapat melakukan pengawasan dan evaluasi terhadap kinerja tenaga pendamping. Tenaga pendamping juga tidak menyampaikan laporan kepada BPMPD kabupaten terhadap kegiatan yang dilakukan oleh tenaga pendamping tersebut.

Selain dari sisi efisiensi, penggunaan Dana Desa akan lebih optimal apabila digunakan secara efektif. Suatu kegiatan dikatakan efektif ketika hasil yang dicapai sesuai atau memenuhi target yang ditetapkan. Hasil site-visit ke salah satu lokasi proyek desa observasi ditemukan bahwa terdapat proyek yang tidak selesai dikerjakan. Dana Desa telah diserap seluruhnya serta telah dilaporkan secara tertib, namun hal tersebut berbanding terbalik dengan efektifitas penggunaan Dana Desa karena proyek yang masih terbengkalai. Realisasi Dana Desa tersebut tidak efektif dalam memberikan manfaat kepada masyarakat karena fisik bangunan kantor desa tidak selesai dikerjakan. Lokasi pembangunan kantor desa juga tidak berada pada lokasi yang strategis karena tidak mudah dijangkau dan harus melalui jalan setapak terlebih dahulu.

Berdasarkan wawancara dengan masyarakat salah satu desa observasi, pembangunan kantor desa merupakan aspirasi warga dikarenakan belum adanya kantor desa sehingga dalam musrenbangdes diputuskan untuk membangun kantor desa. Masyarakat mengeluhkan karena hanya dilibatkan pada saat penyusunan rencana penggunaan Dana Desa (Musrenbangdes). Pada saat Dana Desa tersebut sudah disalurkan ke desa, masyarakat tidak dilibatkan lagi pada kegiatan perencanaan teknis dan rancangan biaya sehingga jumlah biaya yang digunakan untuk membangun kantor desa masyarakat tidak mengetahui.

Secara peraturan, keterlibatan masyarakat hanya pada saat perumusan kegiatan yang akan dibiayai dengan menggunakan Dana Desa dalam bentuk keterwakilan anggota masyarakat dalam kegiatan musrenbangdes. Penentuan besarnya alokasi pembangunan maupun pembuatan $\mathrm{RAB}$ 
merupakan kewenangan dari perangkat desa. Sosialisasi Dana Desa menjadi perlu diberikan kepada masyarakat bukan hanya kepada perangkat desa sehingga tidak terjadi kesalahpahaman antara masyarakat dan perangkat desa yang dapat memicu konflik. Hasil konfirmasi kepada pihak BPMPD Kabupaten/Kota, sosialisasi Dana Desa memang direncanakan akan dilakukan dan pihak DPRD telah mendorong agar dilakukan sosialisasi secara masif kepada masyarakat tidak hanya kepada perangkat desa. Sosialisasi akan membangun kesepahaman antara masyarakat dan perangkat desa mengenai penggunaan Dana Desa sekaligus mendorong partisipasi masyarakat secara aktif untuk melakukan pengawasan penggunaan Dana Desa. Dalam rangka menciptakan transparansi, APBDes dapat diumumkan kepada warga melalui papan pengumuman desa atau diedarkan kepada seluruh masyarakat. Selain itu, papan proyek yang memuat alokasi dana dan jangka waktu pekerjaan seharusnya dipasang di lokasi proyek yang dibiayai Dana Desa sehingga dapat diketahui oleh masyarakat besarnya dana yang digunakan maupun jangka waktu pekerjaan fisik. Hasil observasi dan wawancara kepada masyarakat mendapatkan hasil bahwa tidak terdapat papan proyek atas pekerjaan fisik yang menggunakan Dana Desa, hal ini juga sesuai dengan hasil penelahaan dokumen RAB yang tidak terdapat alokasi dana untuk papan proyek tersebut.

Berdasarkan wawancara kepada masyarakat salah satu desa observasi, pembangunan kantor desa tidak melibatkan masyarakat. Pekerjaan pembangunan kantor desa dilaksanakan oleh masyarakat dari luar desa termasuk bahan baku di peroleh dari luar wilayah, dan ditengarai oleh masyarkat bahwa proyek pembangunan dikerjakan oleh perusahaan kontraktor. Hal ini kurang sesuai dengan semangat pelaksanaan pembangunan fisik dari Dana Desa yang seharusnya mengutamakan pelaksanaan secara swakelola berupa pelibatan masyarakat sebagai tenaga kerja guna menambah kesejahteraan masyarakat.

Contoh baik yang dapat ditiru oleh desa lainnya dalam hal keterlibatan partisipasi masyarakat dalam pelaksanaan kegiatan pembangunan fisik dilakukan oleh Desa Bobanehena. Desa ini melakukan kegiatan pembangunan saluran air yang dilaksanakan secara swakelola dengan tenaga kerja berasal dari masyarakat desa sendiri. Upah tenaga kerja yang diperoleh oleh masyarakat desa Bobanehena tidak dibayarkan secara penuh namun sebagian dipotong sesuai kesepakatan bersama untuk menambah dana pembangunan mesjid.
Praktek pengelolaan Dana Desa ini dapat ditiru oleh desa lainnya, tidak hanya bermanfaat dalam menambah penghasilan namun juga dapat menambah fasilitas umum dan fasilitas sosial yang bermanfaat bagi masyarakat desa itu sendiri. Pelaksanaan pembangunan fisik yang dilakukan secara swakelola sebaiknya menyesuaikan dengan masa produktif penggunaan tenaga kerja di desa. Pelaksanaan pembangunan fisik sebisa mungkin dilakukan pada saat tidak musim panen sehingga upah yang diterima dapat menjadi penyangga penghasilan. Upah yang diberikan sebaiknya di bawah rata-rata penghasilan yang diterima oleh masyarakat agar tidak terjadi peralihan tenaga kerja dari semula menjadi nelayan atau petani beralih menjadi buruh proyek. Pemotongan upah seperti yang dilakukan oleh desa Bobanehena dapat dilakukan tidak hanya untuk menambah dana pembuatan fasilitas umum tetapi dapat juga digunakan sebagai penambah modal badan usaha bersama, tentunya harus ada kesepakataan terlebih dahulu antara masyarakat dan pemerintah desa serta dilakukan secara transparan.

Permasalahan lainnya dari aspek penggunaan Dana Desa adalah masalah perpajakan. Pada dasarnya Dana Desa bersumber dari APBN sehingga tidak terlepas dari kewajiban perpajakan. Sesuai dengan ketentuan perundangundangan, kepala desa, bendahara desa beserta perangkat desa lainnya sebagai pelaksana teknis bertanggung jawab terhadap pengelolaan keuangan desa. Dalam pengelolaan keuangan desa tersebut, bendahara desa bertugas sebagai Wajib Pungut Pajak Penghasilan dan Pajak lainnya yang wajib menyetorkan seluruh penerimaan potongan pajak yang dipungutnya ke rekening kas negara sesuai dengan ketentuan (Pasal 31 Permendagri Nomor 113 Tahun 2014). Ketentuan perpajakan yang selama ini berlaku bagi bendahara pemerintah juga berlaku bagi bendahara desa.

Salah satu indikator keberhasilan pengelolaan Dana Desa dapat dilihat dari sejauh mana kepatuhan dalam pemenuhan kewajiban perpajakannya. Oleh karena itu, penting jika dalam pengelolaan Dana Desa selalu memperhatikan seluruh aspek perpajakannya. Berdasarkan wawancara kepada perangkat desa observasi, secara umum telah menyadari adanya kewajiban perpajakan terhadap penggunaan Dana Desa. Kesadaran yang tinggi atas kewajiban perpajakan tersebut mendorong perangkat desa Bobanehena untuk berkonsultasi ke Kantor Pelayanan Pajak (KPP) Pratama Tobelo (Halbar termasuk dalam wilayah kerja KPP Pratama Tobelo). Konsultasi dilakukan untuk mendapatkan informasi dan bimbingan teknis besarnya pajak yang harus disetor atas penggunaan Dana Desa 
tahun 2015. Bersamaan dengan konsultasi tersebut dilakukan penyetoran pajak yang telah dipungut di bank persepsi di wilayah Tobelo. Kesadaran yang tingi dan partisipasi aktif dari pemerintah desa harus didukung sepenuhnya oleh KPP.

Kesulitan yang dihadapi oleh seluruh bendahara desa di wilayah Kabupaten Halmahera Barat apabila ingin berkonsultasi harus ke KPP Pratama Tobelo yang memakan waktu dan biaya yang tidak sedikit. KPP Pratama Tobelo telah membuka pos pelayanan pajak di Kabupaten Halmahera Barat dengan periode pelayanan sebulan sekali yaitu setiap tanggal 20 bertempat di kantor DPKAD Kab. Halmahera Barat. Pemberitahuan adanya pos pelayanan pajak tersebut perlu dilakukan secara luas. Sosialisasi perpajakan bagi bendahara desa juga perlu dilakukan secara intensif. Permasalahan lainnya terkait perpajakan yaitu kesulitan dalam melakukan penyetoran pajak. Keterangan dari kepala desa observasi menyatakan bahwa untuk melakukan penyetoran pajak harus terlebih dahulu ke Kota Ternate. Hal ini tentu menimbulkan biaya dan menyita waktu. Sosialisasi penyetoran pajak melalui layanan MPN G-2 (e-billing) kepada bendahara desa tampaknya perlu dilakukan dengan kerjasama antara Kanwil Ditjen Perbendaharaan, KPP, maupun bank persepsi.

\subsection{Analisis Pelaporan Dana Desa}

Berdasarkan hasil observasi di lapangan maupun wawancara dengan pihak terkait, pada awalnya hampir seluruh desa observasi mengalami kesulitan dalam menyusun laporan Dana Desa terutama yang berhubungan dengan sistem pembukuan sebagaimana telah ditetapkan dalam Peraturan Menteri Dalam Negeri No 113 Tahun 2014. Namun demikian, setelah beberapa kali dilakukan asistensi oleh pihak BPMPD, DPKAD Kabupaten/Kota maupun pendamping desa maka seiring waktu pihak desa menjadi terbiasa dengan pembukuan tersebut. Penyusunan laporan masih dilakukan secara manual menggunakan Microsoft Excel dengan proses input yang masih begitu manual (tidak menggunakan rumus-rumus tertentu). Hal ini tentunya bisa menimbulkan masalah validitas data. Walaupun demikian, dengan adanya pendampingan dari kabupaten/kota membawa pengaruh positif bagi keberhasilan administrasi pelaporan. Terkait keberadaan tenaga pendamping, beberapa desa mengakui sangat terbantu dengan adanya tenaga tersebut akan tetapi tingkat kehadirannya dirasa masih kurang karena sering tidak berada di tempat.
Dalam hal transparansi dan akuntabilitas, beberapa desa observasi belum mempublikasikan pelaporannya di media yang tersedia seperti balai desa. Tentunya hal ini perlu diperbaiki mengingat bahwa adanya transparansi dapat meningkatkan partisipasi masyarakat terkait penggunaan Dana Desa termasuk dapat memberikan masukan maupun saran perbaikan.

\section{KESIMPULAN DAN SARAN}

\subsection{Kesimpulan}

Berdasarkan uraian yang telah dipaparkan dapat disimpulkan sebagai berikut:

a. Pengalokasian Dana Desa

1. Perhitungan alokasi dasar dan alokasi formula 90\%:10\% menyebabkan kurang proporsionalnya distribusi Dana Desa apabila dikaitkan dengan status/kondisi desa sebagaimana dituangkan dalam IDM. Alokasi demikian kurang mampu mengurangi ketimpangan dan ketertinggalan utamanya bagi desa dengan status tertinggal/sangat tertinggal.

2. Luas wilayah desa meskipun hanya diberi bobot $10 \%$ dari alokasi formula namun cukup mempengaruhi alokasi formula Dana Desa yang diperoleh masing-masing desa.

b. Penyaluran Dana Desa

1. Masih terdapat keterlambatan Penyaluran Dana Desa dari RKUN ke RKUD. Penyebab keterlambatan tersebut disebabkan keterlambatan penyampaian peraturan kepala daerah tentang tata cara pembagian dan penetapan rician Dana Desa serta keterlambatan penyampaian laporan penyaluran dan penggunaan Dana Desa.

2. Penyaluran Dana Desa dari RKUD ke RKD juga masih ditemui adanya keterlambatan. Hal ini merupakan konsekuensi lanjutan atas terlambatnya Dana Desa yang masuk ke RKUD. Selain itu juga disebabkan keterlambatan desa dalam menyampaikan peraturan kepala desa tentang APBDesa serta keterlambatan penyampaian laporan penggunaan Dana Desa tahap sebelumnya.

3. Salah satu faktor yang turut berperan dalam menyebabkan pemda tidak dapat menyalurkan Dana Desa dari RKUD ke RKD sesuai norma waktu adalah kurangnya harmonisasi pengaturan 
antara persyaratan penyaluran dari RKUN ke RKUD dengan penyaluran dari RKUD ke RKD sebagaimana diatur dalam Peraturan Menteri Keuangan mengenai tata cara penyaluran Dana Desa. Hal tersebut dapat terjadi karena pada saat Dana Desa telah masuk ke RKUD perlu diantisipasi dengan kesiapan desa dalam memenuhi persyaratan penyaluran dari RKUD ke RKD.

4. Keterlambatan penyaluran dapat menimbulkan dampak opportunity loss berupa kerugian sisi waktu dan kesempatan dalam mengeksekusi program Dana Desa serta kerugian terkait lainnya.

5. Keterlambatan penyaluran dari RKUD ke RKD menyebabkan adanya pengendapan Dana Desa pada rekening pemda di perbankan sehingga kurang produktif jika dilihat dari sisi pengelolaan Kas Negara.

\section{c. Penggunaan Dana Desa}

1. Penggunaan Dana Desa yang telah sesuai prioritas pada tahun 2015 bervariasi mulai dari: (i) pelaksanaan pembangunan untuk pemenuhan kebutuhan dasar berupa pembangunan posyandu, polindes, dan PAUD; (ii) pembangunan sarana prasarana desa berupa pembangunan badan jalan desa, jalan setapak, rabat beton, deker, drainase, dan pengadaan air bersih; (iii) pembangunan untuk pengembangan potensi ekonomi lokal berupa pendirian BUMDesa/Koperasi.

2. Terdapat beberapa penggunaan Dana Desa yang kurang sesuai prioritas/ketentuan pada tahun 2015 berupa: (i) pembangunan kantor desa; (ii) pembangunan pos pelabuhan; (iii) kegiatan pelatihan perangkat desa; (iv) penunjang kegiatan keagamaan, posyandu, karang taruna.

3. Penyebab tidak selarasnya prioritas penggunaan Dana Desa karena bias penerjemahan dua regulasi yang berbeda. Permendes memberikan rambu-rambu bahwa prioritas Dana Desa digunakan dalam rangka pelaksanaan pembangunan dan pemberdayaan masyarakat desa. Sementara Permendagri memberikan ketentuan bahwa sepanjang pelaksanaan program telah melalui perencanaan/musyawarah dan tertuang dalam APBDesa maka hal tersebut menjadi sah.
4. Besaran Dana Desa yang semakin meningkat pada tahun 2016 memberikan ruang fiskal yang lebih fleksibel bagi desa untuk memberikan prioritas pada bidang pelaksanaan pembangunan maupun pemberdayaan masyarakat desa.

5. Kegiatan pelaksanaan pembangunan yang dibiayai dari Dana Desa pada tahun 2016 cukup bervariasi mulai dari: (i) pembangunan sarana fisik untuk penghidupan berupa pembangunan jalan desa, drainase, tembok, deker, sumur bor; (ii) pembangunan sarana prasarana pendidikan, sosial budaya berupa pembangunan gedung PAUD, gedung pembelajaran keagamaan; (iii) pembangunan sarana ekonomi masyarakat berupa bangunan pariwisata, dan bangunan BUMDesa.

6. Terdapat beberapa kegiatan pelaksanaan pembangunan yang dinilai kurang tepat dari sisi penggunaan Dana Desa tahun 2016 berupa pembebasan lahan TPU desa dan pembangunan sarana kompleks kuburan.

7. Dana Desa untuk kegiatan pemberdayaan masyarakat desa lebih banyak digunakan untuk kegiatan pelatihan kepala desa dan perangkat desa, lomba PKK, pemberian insentif/honor, serta seragam posyandu. Hal ini kurang berkorelasi langsung dengan kegiatan promosi dan edukasi kesehatan masyarakat yang merupakan bagian dari pemberdayaan masyarakat.

8. Telah terdapat keterkaitan antar dokumen perencanaan dalam rangka penggunaan Dana Desa. Program/kegiatan yang terdapat pada APBDesa (yang didanai dari Dana Desa) telah direncanakan di dalam RKP Desa maupun RPJM Desa. Keterkaitan paling kuat terdapat pada APBDesa dengan RKP Desa. Sementara itu, keterkaitan antara RKP Desa dengan RPJM Desa memang telah terpenuhi, namun demikian perlu difokuskan kembali rencana yang tertuang dalam jangka menengah.

9. Pada tahun 2015 dan 2016 secara umum tidak terdapat program yang mengalami tumpang tindih baik yang dibiayai dari Dana Desa maupun yang dibiayai dari APBD namun jika tidak diatur sedemikian rupa maka dapat menimbulkan potensi tumpang tindih pembiayaan di masa mendatang. Beberapa pokok permasalahan yang dapat menyebabkan terjadinya potensi tumpang tindih 
pembiayaan program yaitu: (i) kewenangan desa dalam melaksanakan pembangunan telah jelas tertuang dalam hak asal usul dan kewenangan berskala lokal desa, namun karena masih terbatasnya sumber Dana Desa mengakibatkan adanya urusan desa yang dibiayai dari APBD; (ii) terdapat area abuabu dalam hal jenis kegiatan maupun lokasi pembangunan serupa yang dapat menyimpan potensi tumpang tindih pembiayaan jika tidak dilakukan koordinasi yang baik antar tingkat pemerintahan.

10. Terdapat kegiatan pemberdayaan masyarakat yang berpotensi tumpang tindih dengan kegiatan yang dibiayai dari dana APBN/APBD yaitu pemberian beasiswa bagi anak sekolah. Kegiatan tersebut tidak sesuai dengan prioritas penggunaan Dana Desa bidang pemberdayaan masyarakat dan juga berpotensi tumpang tindih dengan kegiatan Bantuan Siswa Miskin atau Program Indonesia Pintar yang dibiayai dari dana APBN.

11. Dari sisi optimalisasi, Dana Desa tahun 2015 telah digunakan seluruhnya atau dengan kata lain realisasi penggunaan telah mencapai $100 \%$.

12. Masih ditemukan adanya perbedaan harga satuan yang digunakan dalam penyusunan RAB antar satu desa dengan desa lainnya, walaupun desa tersebut berdekatan dan terletak dalam satu kecamatan. Hal ini terjadi karena belum adanya keseragaman harga satuan yang digunakan, dan pemahaman pemerintah desa dalam menyusun RAB yang belum memadai, serta evaluasi atas RAPBDes yang belum optimal.

13. Terdapat kesulitan yang dihadapi oleh bendahara desa dalam hal perpajakan berupa kesulitan dalam melakukan penyetoran pajak maupun konsultasi perpajakan karena aspek lokasi.

d. Pelaporan Dana Desa

1. Pada awalnya, desa observasi mengalami kesulitan dalam hal administrasi pelaporan namun dengan adanya pendampingan dari kabupaten/kota menjadikan masalah tersebut dapat diatasi.

2. Pelaporan dan pembukuan Dana Desa masih dilakukan secara manual.
3. Dalam hal transparansi dan akuntabilitas, beberapa desa observasi belum mempublikasikan pelaporannya di media yang tersedia seperti balai desa.

\subsection{Saran}

a. Dari sisi kebijakan, pemerintah pusat perlu lebih mengharmonisasi komposisi alokasi dasar dan alokasi formula disesuaikan dengan kebutuhan dan potensi desa berdasarkan status kemajuan/kemandirian desa (IDM). Pengalokasian berdasarkan pola zona/kawasan di Indonesia dapat dipertimbangkan untuk pemerataan pembangunan. Sementara itu, luas wilayah yang berpengaruh cukup besar dalam alokasi Dana Desa perlu mempertimbangkan komponen sebaran penduduk dalam suatu wilayah karena pada dasarnya pembangunan desa lebih kepada pembangunan manusia.

b. Untuk menghindari adanya ketidakpatuhan atas norma waktu 7 hari penyaluran dari RKUD ke RKD, sebaiknya dilakukan harmonisasi terkait pengaturan persyaratan penyaluran dari RKUN ke RKUD dan dari RKUD ke RKD. Salah satu persyaratan yang dapat dijadikan pertimbangan adalah pada tahapan penyaluran dari RKUN ke RKUD agar juga memperhatikan penyelesaian/ penyusunan perdes tentang APBDesa dan penyusunan laporan penggunaan Dana Desa tahap sebelumnya sehingga nantinya proses penyaluran dari RKUD ke RKD dapat berjalan lancar sesuai jadwal yang ditetapkan.

c. Pola keterlambatan yang terjadi dalam penyaluran Dana Desa juga perlu diperbaiki melalui upaya peningkatan kapasitas dan manajerial dari perangkat desa serta optimalisasi peran pendamping desa sehingga kendala teknis dapat diatasi.

d. Dalam upaya mencapai ketepatan penggunaan Dana Desa, beberapa kebijakan perlu diambil misalnya: (i) mempertegas rambu-rambu bahwa untuk desa tertinggal/sangat tertinggal, Dana Desa hanya diperuntukkan bagi pembangunan sarana prasarana kebutuhan dasar dan akses penghidupan sementara pembangunan sarana lainnya menggunakan sumber dana selain Dana Desa; (ii) untuk desa tertinggal/sangat tertinggal dapat menggunakan Dana Desa untuk pembangunan sarana prasarana secara pararel namun tetap harus memperhatikan prioritas tertinggi bagi pemenuhan sarana prasarana kebutuhan dasar dan akses penghidupan masyarakat. 
e. Diperlukan adanya grand design dari pemerintah daerah supaya penggunaan Dana Desa menjadi lebih jelas dan terarah.

f. Pada bidang pemberdayaan masyarakat, Dana Desa akan lebih bermanfaat jika berfokus pada kegiatan peningkatan kapasitas masyarakat desa seperti kegiatan pelatihan wirausaha, manajemen usaha BUMDes, pelatihan membuat kerajinan, serta kegiatan promosi dan edukasi kesehatan masyarakat.

g. Perlu difokuskan kembali rencana yang tertuang dalam jangka menengah (RPJM Desa).

h. Perlu dipertegas kembali mengenai pemisahan kewenangan berupa penetapan regulasi kewenangan lokal berskala desa di tiap kabupaten/kota serta perlunya pelaksanaan mekanisme koordinasi antar tingkatan pemerintahan agar tidak menimbulkan potensi tumpang tindih pembiayaan di masa mendatang.

i. Dalam rangka meningkatkan efisiensi dan efektivitas, perlu keterlibatan beberapa pihak misalnya Dinas Pekerjaan Umum Kabupaten/kota dengan mengambil peranan berupa pemberian asistensi penyusunan RAB serta desain teknis pembangunan infrastruktur. Peran dari tenaga pendamping desa juga perlu ditingkatkan baik dalam penyusunan RAB maupun lainnya.

j. Diperlukan adanya pembuatan standar biaya dalam pelaksanaan Dana Desa, namun demikian tentunya bersifat khusus karena pertimbangan terkait dengan semangat pemberdayaan dan swakelola.

k. Diperlukan Sosialisasi secara masif kepada seluruh masyarakat desa sehingga tercipta kesepahaman antara masyarakat dan perangkat desa mengenai penggunaan Dana Desa sekaligus mendorong partisipasi masyarakat secara aktif untuk melakukan pengawasan penggunaan Dana Desa

l. Pelaksanaan pembangunan fisik yang dilakukan secara swakelola sebaiknya menyesuaikan dengan masa produktif penggunaan tenaga kerja di desa. Pelaksanaan pembangunan fisik sebisa mungkin dilakukan pada saat tidak musim panen sehingga upah yang diterima dapat menjadi penyangga penghasilan.

m. Untuk mengatasi kesulitan dalam hal perpajakan Dana Desa, Kantor Pelayanan Pajak (KPP) di wilayah Maluku Utara dapat melakukan sosialisasi perpajakan bagi bendahara desa secara luas dan intensif.
Sosialisasi penyetoran pajak melalui layanan MPN G-2 (e-billing) kepada bendahara desa tampaknya perlu dilakukan dengan kerjasama antara Kanwil Ditjen Perbendaharaan, KPP, maupun bank persepsi.

n. Diperlukan peningkatan kapasitas SDM perangkat desa untuk mendukung pelaporan yang lebih baik.

o. Untuk meningkatkan transparansi dan akuntabilitas penggunaan Dana Desa perangkat desa agar mempublikasikan Anggaran Pendapatan dan Belanja Desa dan Laporan Realisasi Penggunaan Dana Desa secara periodik pada papan pengumuman yang tersedia di balai desa.

\section{IMPLIKASI DAN KETERBATASAN}

Penelitian ini memiliki keterbatasan dari sisi waktu penelitian dan jumlah sampel penelitian. Waktu penelitian dapat diperpanjang sehingga observasi yang dilakukan dapat lebih lama dan melihat seluruh tahapan proses pelaksanaan Dana Desa. Sampel penelitian Dana Desa dapat diperluas untuk seluruh kabupaten/kota di wilayah Maluku Utara dan dapat diperluas lagi cakupannya menjadi berskala nasional.

\section{PENGHARGAAN (ACKNOWLEDGEMENT)}

Ucapan terima kasih disampaikan kepada Kepala Kanwil Ditjen Perbendaharaan Provinsi Maluku Utara, Tri Budhianto dan seluruh rekanrakan Tim Kajian Dana Desa Provinsi Maluku Utara yang terlibat dalam penelitian ini antara lain: Gandung Triyasmoko, Made Krisna Aryawan, Yosi Rizal Adyanto, Rahmatullah, Yonas Kesuma Mangende, dan Sunyoto.

\section{DAFTAR PUSTAKA (REFERENCES)}

Abidin, Muhammad Zainul. (2015). Tinjauan atas Pelaksanaan Keuangan Desa dalam Mendukung Kebijakan Dana Desa. Jurnal Ekonomi dan Kebijakan Publik. Vol. 6. No. 1, hlm. 61-76.

Ardhi, Ilyasa. (2016). Keterlambatan Penyaluran Dana Desa. Indonesian Treasury Review. Vol. 1. No. 3, hlm. 35-48.

Badan Pusat Statistik Provinsi Maluku Utara. (2014). Statistik Potensi Desa Provinsi Maluku Utara 2014 Penyajian Level Kecamatan. Ternate: BPS.

Bergvall, Daniel, et al. (2006). Intergovernmental Transfers and Decentralised Public Spending. OECD Journal on Budgeting. Vol. 5 No. 4. 
Falleti, Tulia G. A. (2014). Sequential Theory of Decentralization and Its Effects On The Intergovernmental Balance Of Power: Latin American Cases in Comparative Perspective.

Harjowiryono, M. (2012). Pengembangan Sistem Pembiayaan Antar Pemerintah di Indonesia, Desentralisasi Fiskal di Indonesia Satu Dekade setelah Ledakan Besar. Jakarta: DJPK

Komisi Pemberantasan Korupsi. (2015). Laporan Hasil Kajian Pengelolaan Keuangan Desa: Alokasi Dana Desa dan Dana Desa. Jakarta: KPK.

Mardiasmo. (2004). Otonomi dan Manajemen Keuangan Daerah. Yogyakarta: Penerbit Andi.

Tarigan, A. (2005). "Rural - Urban Economic Lingkages" Konsep dan Urgensinya Dalam Memperkuat Pembangunan Desa. Jakarta: BAPPENAS.

Peraturan Menteri Dalam Negeri Nomor 113 Tahun 2014 tentang Pengelolaan Keuangan Desa.

Peraturan Menteri Desa, Pembangunan Daerah Tertinggal, dan Transmigrasi RI Nomor 1 Tahun 2015 tentang Pedoman Kewenangan Berdasarkan Hak Asal Usul dan Kewenangan Lokal Berskala Desa.

Peraturan Menteri Desa, Pembangunan Daerah Tertinggal, dan Transmigrasi RI Nomor 5 Tahun 2015 tentang Penetapan Prioritas Penggunaan Dana Desa Tahun 2015.

Peraturan Menteri Desa, Pembangunan Daerah Tertinggal, dan Transmigrasi RI Nomor 21 Tahun 2015 tentang Penetapan Prioritas Penggunaan Dana Desa Tahun 2016.

Peraturan Menteri Desa, Pembangunan Daerah Tertinggal, dan Transmigrasi RI Nomor 2 Tahun 2016 tentang Indeks Desa Membangun.

Peraturan Menteri Keuangan RI Nomor 247/PMK.07/2015 tentang Tata Cara Pengalokasian, Penyaluran, Penggunaan, Pemantauan, dan Evaluasi Dana Desa.

Peraturan Menteri Keuangan RI Nomor 49/PMK.07/2016 tentang Tata Cara Pengalokasian, Penyaluran, Penggunaan, Pemantauan, dan Evaluasi Dana Desa.

Peraturan Pemerintah Nomor 43 Tahun 2014 tentang Peraturan Pelaksanaan Undang Undang Nomor 6 tahun 2014 Tentang Desa.

Peraturan Pemerintah Nomor 60 Tahun 2014 tentang Dana Desa yang Bersumber dari Anggaran Pendapatan dan Belanja Negara.
Peraturan Pemerintah Nomor 22 Tahun 2015 tentang Perubahan Peraturan Pemerintah Nomor 60 Tahun 2014 tentang Dana Desa yang Bersumber dari Anggaran Pendapatan dan Belanja Negara.

Undang-Undang Nomor 6 Tahun 2014 tentang Desa.

http://www.sapa.or.id/b1/132-pmk/9839-danadesa-mlenceng-kdjfj (diakses pada tanggal 13 Juli 2016). 